\title{
SOMATOMEDIN C IN DAIRY COWS RELATED TO ENERGY AND PROTEIN SUPPLY AND TO MILK PRODUCTION
}

\author{
H. Ronge', J. Blum ${ }^{\dagger}+$, C. Clement ${ }^{1}$, F. Jans ${ }^{2}$, H. Leuenberger ${ }^{3}$ and H. Binder ${ }^{4}$ \\ 'Department of Nutrition Pathology, Institute of Animal Breeding, University of Berne, School \\ of Veterinary Medicine, 3012 Berne, Switzerland \\ ${ }^{2}$ Federal Research Station for Animal Production, Grangeneuve, 1725 Posieux, Switzerland \\ ${ }^{3}$ Institute of Animal Science, Federal Institute of Technology, 8092 Zurich, Switzerland \\ ${ }^{4}$ Institute of Animal Breeding, University of Zurich, School of Veterinary Medicine, 8057 \\ Zurich, Switzerland
}

\begin{abstract}
Somatomedin $\mathrm{C}$ and other hormones, as well as blood metabolites, were measured during the dry period and during lactation in dairy cows, given different amounts of energy and protein, to study metabolic and endocrine adaptations. Somatomedin $C$, specifically measured by radioimmunoassay after separation from its binding protein, did not exhibit typical diurnal variations, in contrast to somatotropin and insulin, which increased particularly after concentrate intake. Somatomedin $\mathrm{C}$ markedly decreased at parturition and reached lowest values around the peak of lactation, while levels of somatotropin, nonesterified fatty acids and ketone bodies were high and those of glucose, insulin, thyroxine and triiodothyronine were low. Thereafter somatomedin $\mathrm{C}$ values slowly increased up to the 12th week of lactation and remained elevated. Low energy and protein balances were characterized by particularly low somatomedin $\mathrm{C}$ concentrations. An additional protein deficit at peak lactation, when cows were already provided with low amounts of energy, did not further decrease somatomedin C levels. However, when high amounts of energy were given in the form of starch or crystalline fat, somatomedin $\mathrm{C}$ increased. Overall, there was a positive correlation of somatomedin $\mathrm{C}$ primarily with energy, but also with protein balances and a negative correlation with milk yield. Conversely, somatotropin increased markedly after parturition and was positively correlated with milk production and negatively with protein and energy balances. Thus, somatomedin C levels were paradoxically low in the presence of high circulating somatotropin. Insulin most closely paralleled somatomedin $\mathrm{C}$ levels. Therefore the anabolic state of metabolism at the end of pregnancy was characterized by high somatomedin $\mathrm{C}$ and insulin and relatively low somatotropin, whereas the catabolic state of early lactation was characterized by high somatotropin, low somatomedin $\mathrm{C}$, insulin and thyroid hormones.
\end{abstract}

\section{INTRODUCTION}

High-yielding dairy cows are usually characterized by negative energy and protein balances during the first weeks of lactation (Moe, 1981; Chilliard, Rémond, Sauvant and Vermorel, 1983). During early lactation metabolism is changed towards enhanced mobilization and utilization of fat whereas glucose utilization in organs other than the mammary gland is reduced (Bennink, Mellenberger, Frobish and Bauman, 1972; Bauman and Currie, 1980; Rémésy, Chilliard,

† To whom correspondence should be addressed.
Rayssiguier, Mazur and Démigné, 1986; Chilliard, 1987). Marked endocrine changes occur that are considered responsible for the shift from a largely anabolic metabolic state during late pregnancy towards a primarily catabolic state in early lactation (Bauman and Currie, 1980; Tucker, 1981; Hart, 1983; Collier, McNamara, Wallace and Dehoff, 1984; Kunz and Blum, 1985; Kunz, Blum, Hart, Bickel and Landis, 1985; Karg and Mayer, 1987).

Somatotropin (STH), circulating in blood in relatively high amounts particularly during early lactation, decreases lipogenesis, favours 
lipolysis and gluconeogenesis, enhances nitrogen retention and stimulates milk yield (Hart and Johnsson, 1986; McCutcheon and Bauman, 1986), although receptors for STH are not present in mammary tissue (Tucker and Merkel, 1987). However, several of the effects of STH are well known to be mediated by somatomedin $\mathrm{C}$ (SmC). Importantly, receptors for $\mathrm{SmC}$ exist in mammary tissue (Campbell and Baumrucker, 1986). Therefore SmC might be responsible for STH effects on mammary tissue and could mediate, at least in part, STH effects on milk yield. Bovine $\mathrm{SmC}$ is identical with human SmC and with insulin-like growth factor I (Klapper, Svoboda and Wyk, 1983; Honegger and Humbel, 1986). It seems mainly to be synthesized by the liver.

Because blood $\mathrm{SmC}$ levels are modified in rats, humans, steers and heifers by variations in protein and/or energy intake (Breier, Bass, Butler and Gluckman, 1986; Elsasser, Rumsey and Hammond, 1986; Underwood, Clemmons, Maes, D'Ercole and Ketelslegers, 1986) and somatomedin-like activity (determined by bioassay) is reduced in lactating cows with insufficient energy intake or high milk production (Falconer, Forbes, Bines, Roy and Hart, 1980; Binnerts, Adrichem, Oudenaarden, Vogt and Wassenaar, 1982), we have studied changes of $\mathrm{SmC}$ levels by use of a specific radioimmunoassay in highyielding dairy cows, given different amounts of energy and/or protein.

\section{MATERIAL AND METHODS}

\section{Experimental design and feeding}

Four studies (A, B, C and D) were performed: over an entire lactation (A), under different feeding conditions from 2 weeks before to 12 weeks after parturition (B and $\mathrm{C}$ ), and as a 24-h experiment during the 4 th or 5 th week of lactation under different feeding conditions (D).

\section{Experiment $A$}

Animals. Ten dairy cows (Schweizerisches Braunvieh) in their second lactation were examined for 300 days. Three of them were non-pregnant whereas the other seven were successfully inseminated between the 8th and 20 th week of lactation.

Feeding. The animals were fed individually and received hay ad libitum and $2 \mathrm{~kg}$ barley. When they produced more than $13 \mathrm{~kg}$ milk, concentrates $(1 \mathrm{~kg} / 2 \mathrm{~kg}$ milk; containing cereals, soya-bean meal, vitamins and minerals) were fed in addition. The experiment was performed and the animals were held at the Institute for Animal Breeding at the University of Zurich (Binder, 1986). Blood samples were taken every 2nd day from 2 to 80 days, and then every 5 th day up to 300 days.

\section{Experiment $B$}

Animals. Thirty dairy cows (16 HolsteinFriesian, eight Simmental and six Schweizerisches Braunvieh $\times$ Brown Swiss) were divided equally by breed and numbers of lactation into two groups, each consisting of 15 animals: group $\mathrm{HE}$ was fed high amounts of energy and protein using concentrates; group LE was fed low amounts of energy and protein by omitting the concentrates.

The animals were held at the Research Station of the Institute of Animal Science, Federal Insititute of Technology, Zurich (Leuenberger, Kunz and Michel, 1987). Blood samples were taken once weekly.

Feeding. Both groups were fed individually a ration of $2 / 3$ grass or hay and $1 / 3$ maize silage. Group $\mathrm{HE}$ received concentrates $(450 \mathrm{~g}$ barley, $200 \mathrm{~g}$ wheat, $150 \mathrm{~g}$ oats, $175 \mathrm{~g}$ maize per $\mathrm{kg}$ and vitamins and minerals; supplemented with a soya-bean meal).

\section{Experiment $C$}

Animals. Nineteen animals (one animal had to be treated for ketosis and was eliminated from the experiment) $(12$ Simmental $\times$ Red Holstein, and seven Brown Swiss $x$ Schweizerisches Braunvieh) were divided equally by breed into two groups: group LD was fed normally (according to recommendations), and had a low protein deficit (10 animals); group HD received less protein and therefore had a high protein deficit (nine animals).

Feeding. To $5 \mathrm{~kg}$ hay, concentrates $(315 \mathrm{~g}$ barley, $315 \mathrm{~g}$ maize, $150 \mathrm{~g}$ soya-bean meal, 
$117 \mathrm{~g}$ oats per $\mathrm{kg}$ and molasses, minerals and vitamins; group LD additionally received soya-bean meal) and maize silage were given according to the planned deficit of each animal. In group $\mathrm{HD}$ an additional protein deficit was planned. Planned daily energy and protein balances, based on net energy lactation (NEL) and absorbable protein from the gut (AP) for the 1st, 2nd and 3rd month were: for $\mathrm{LD}-22.5,-12.5$ and $0 \mathrm{MJ}$ NEL and $-125,-25$ and $0 \mathrm{~g} \mathrm{AP}$; for $\mathrm{HD}-32 \cdot 5$, -20 and $0 \mathrm{MJ}$ NEL and $-500,-325$ and $0 \mathrm{~g}$ AP. The animals were held and individually fed at the Federal Research Station for Animal Production in Grangeneuve (F. Jans, unpublished). Blood samples were taken once weekly.

\section{Experiment $D$}

Animals. Eighteen dairy cows (nine Simmental $\times$ Red Holstein, and nine Schweizerisches Braunvieh purebred or $x$ Brown Swiss) were divided equally by breed into three different groups of six animals each: group LE was given low amounts of energy; group $\mathrm{HE}$ received relatively high amounts of energy; group $\mathrm{CF}$ received concentrates supplemented with crystalline fat.

Feeding. The animals received hay and maize silage ad libitum. Concentrates (soyabean meal supplemented with barley, maize, minerals and vitamins) were added as planned. Group CF received $1150 \mathrm{~g}$ crystalline fat per day (Alikon ${ }^{(\mathbb{B})}$; Alifet AG, 4922 Bützberg, Switzerland).

Experiments in the 4th to 5th week of lactation, lasting for 7 days, were carried out at the Swiss Federal Research Station for Animal Production in Grangeneuve (F. Jans, unpublished). Blood samples (39) were taken over a 24-h period (Blum, Jans, Moses, Fröhli, Zemp, Wanner, Hart, Thun and Keller, 1985a) at the last day of the experiment.

In experiments $\mathrm{B}, \mathrm{C}$ and $\mathrm{D}$, energy and protein intake and balances were based on NEL and AP, respectively, and were calculated according to Bickel and Landis (1978) and Landis (1979). Calculations of AP balances were modified by taking milk protein instead of fat-corrected milk (FCM) as a basis ( $1.5 \mathrm{~g} \mathrm{AP}$ for $1 \mathrm{~g}$ milk protein).
Calculations of daily requirements were based on:

maintenance: $0 \cdot 293 \mathrm{MJ}$ NEL per $\mathrm{kg} \mathrm{M}^{1.75}$ and $3.25 \mathrm{~g}$ AP per $\mathrm{kg} \mathbf{M}^{0.75}$

pregnancy (9th month): $18 \mathrm{MJ}$ NEL and $205 \mathrm{~g} \mathrm{AP}$

milk: 3.14 MJ NEL per kg FCM and $1.5 \mathrm{~g}$ AP per $\mathrm{g}$ milk protein.

In experiment $A$, protein intake was measured based on digestible crude protein.

Blood samples were taken at $14.00 \mathrm{~h}$ by jugular venipuncture, using vacutainers (Becton-Dickinson, $\mathrm{CH} 4142$ Müchenstein) or through indwelling catheters (24-h experiments, D), implanted at least $3 \mathrm{~h}$ before the start of the studies. Heparinized blood plasma was used for all determinations, except for the determination of ketone bodies, for which blood was deproteinized with equal amounts of ice-cold perchloric acid $(0.7 \mathrm{~mol} / 1)$.

\section{Laboratory methods}

Glucose, protein, albumin, urea, nonesterified fatty acids (NEFA), ketone bodies ( $\beta$-hydroxybutyrate plus acetoacetate), immunoreactive insulin (IRI), thyroxine $\left(\mathrm{T}_{4}\right)$ and triiodothyronine $\left(T_{3}\right)$ were measured as described before (Blum et al., 1985a).

STH concentrations were determined by radioimmunoassay based on the methods of Hart, Flux, Andrews and McNeilly (1975) with some modifications. STH for standards (USDA-bGH-B-1 AFP-5200) and for iodination (USDA-bGH-I-1 AFP-6500) were obtained from the National Institute of Arthritis, Diabetes and Digestive and Kidney Diseases, Baltimore, MD 21201-3472, USA. Antiserum against bovine rbSTH (bGH $5 / 15.6 .86$ ), raised in a rabbit, was provided by Professor Dr D. Schams, Munich and used at a final dilution of 1:50000. Goat-antirabbit-gamma-globulin, purchased from Antibodies Inc., Davis, CA, USA, fraction $\mathrm{P}_{4}$, was used as second antibody to separate (together with $5 \%$ polyethyleneglycol) the bound from free hormone. STH was labelled using the iodogen procedure (Salacinski, McLean, Sykes, Clement-Jones and Lowry, 1981). rbSTH paralleled bSTH standards obtained from hypothalamic extracts. Halfmaximal binding was attained with $10 \mu \mathrm{g}$ STH 
per $\mathrm{l}$ and the sensitivity was below $1 \mu \mathrm{g} / \mathrm{l}$. Recovery of bovine STH for 1 and $10 \mathrm{ng}$ added $(10 \mu \mathrm{l})$ to $1 \mathrm{ml}$ bovine serum was 117 $\pm 17 \%$ and $107 \pm 6 \%$, respectively. All samples from one animal were measured within the same assay and each sample was determined in triplicate. Intra-assay coefficient of variation and inter-assay variation were below $0 \cdot 050$.

Somatomedin $\mathrm{C}$ was determined in triplicate by radioimmunoassay according to Zapf, Walter and Froesch (1981) with some modifications. SmC (preparation $1 / 3$ and 1/4) used for standards was kindly provided by Professor Dr R. E. Humbel, Zürich, Switzerland. For production of antiserum in a rabbit and for iodination (by the chloramin- $\mathrm{T}$ method), recombinant human $\mathrm{SmC}$ (rSmC, Mü 14 Fr 25-32 TOP), which has the same structure as bovine $\mathrm{SmC}$ or insulin-like growth factor I, was used ( $\mathrm{rSmC}$ was obtained from Professor $\mathrm{Dr}$ Nüesch and $\mathrm{Dr}$ Scheibli, Ciba-Geigy A. G., 4002, Basle, Switzerland). All samples were pretreated with acid/ethanol to separate $\mathrm{SmC}$ from its binding protein(s), as described by Daughaday, Mariz and Blethen (1980). The samples were neutralized with ammonium hydrogen carbonate, lyophilized and reconstituted in the assay buffer before further use. After incubation for $24 \mathrm{~h}$ with antibody and another $24 \mathrm{~h}$ with tracer, antibody-bound and free $\mathrm{SmC}$ were separated after addition of $1 \%$ bovine gamma-globulin and $25 \%$ polyethyleneglycol by centrifugation. Half-maximal binding was $1.0 \mathrm{ng}$ per tube. The sensitivity was below $0.1 \mathrm{ng}$ per tube (less than $6.5 \mu \mathrm{g} / \mathrm{l}$ ). Recovery was $91 \pm 5 \%$ and $111 \pm 9 \%$, respectively, for 10 and $20 \mathrm{ng}$ $\mathrm{rSmC}(10 \mu \mathrm{l})$ added to $1 \mathrm{ml}$ bovine plasma. The recovery of ${ }^{125}$ I-labelled $\mathrm{rSmC}$ added to bovine plasma was $104 \pm 1 \%$. Compared with separation of $\mathrm{SmC}$ bound to plasmaprotein(s) by chromatography using a large column $(30 \times 2 \mathrm{~cm}$, volume $92.5 \mathrm{ml})$ and acidified buffer, recovery by acid/ethanol extraction was increased by $27 \pm 5 \%$. Diluted sera from cattle in different physiological states paralleled the standard curve. Heparin in plasma did not modify the results. Use of an antiserum (115/91177, obtained from Professor J. Zapf, University of Zürich, Switzerland) raised against extracted human SmC gave the same results as obtained with the antiserum raised against $\mathrm{rSmC}$. The intra-assay coefficient of variation and the inter-assay coefficient of variation were below $0 \cdot 1$.

\section{Statistical analysis}

Values are expressed as means and standard errors. Correlations were calculated according to Spearman. They were calculated for each animal separately and are expressed as the mean of individuals. The significance of difference between groups were tested by Wilcoxon-Test $(P<0 \cdot 05)$.

\section{RESULTS}

Changes of SmC and milk yield during a 300day lactation period (experiment $A$ )

The day-to-day coefficient of variation was $0 \cdot 14$ and $0 \cdot 17$ for two animals during the first 80 days of lactation (Figure 1). Following a transient decrease after parturition, SmC levels increased up to 150 days of lactation and then remained elevated. In contrast, milk production (FCM) continuously decreased. There were no significant differences between pregnant and non-pregnant cows (not shown). Energy and protein balances never became negative throughout lactation and increased during the first 2 to 3 months after parturition. SmC and FCM were negatively correlated $(r=-0.61)$, whereas there was a positive correlation of $\mathrm{SmC}$ with energy and protein balances $(r=0.42$ and 0.43 , respectively).

Effects of energy and protein supply on food intake, energy and protein balances, milk yield and composition, metabolites and hormones $\left(S m C, S T H, I R I, T_{3}\right.$ and $T_{4}$ ) during the dry period and the first 3 months of lactation (experiments $B$ and $C$ )

Dry-matter intake of basic ration (BR; grass, hay, maize silage) was relatively low during the dry period, then increased particularly during the 1 st and 2 nd month of lactation, but there were no significant differences between groups LE and HE or LD and HD, respectively (Table 1). Provision 


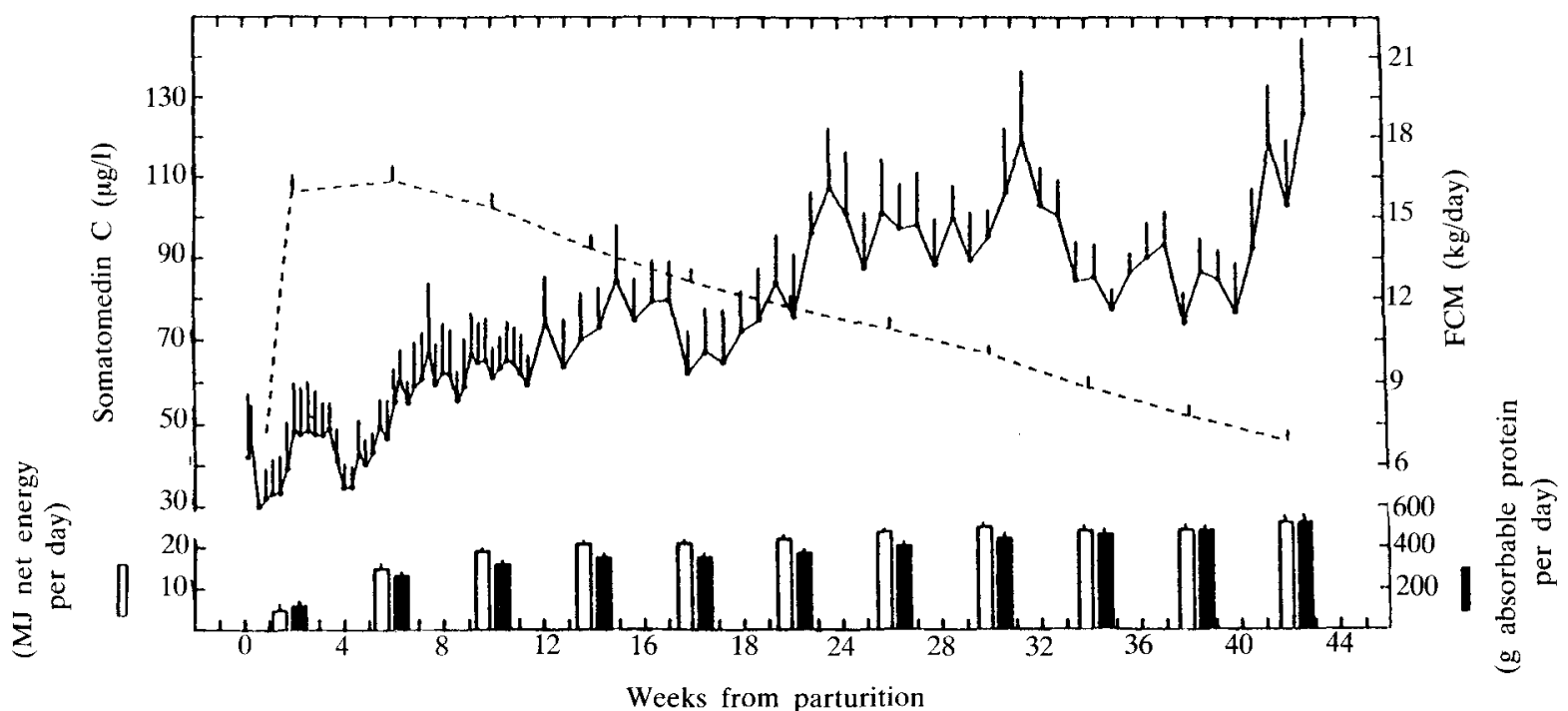

Fig. 1. Blood levels of somatomedin C measured every 2nd day from 2 to 80 days, and every 5 th day up to 300 days; \pm s.e. ( $\longrightarrow$ ), fat-corrected milk yield (FCM) (- - -), energy (MJ net energy per day $\square$ ) and protein (g absorbable protein per day balances (average calculated for 4 weeks; during a 300-day lactation period (experiment $\mathrm{A}$ ).

of concentrates (C) was increased during lactation compared with the dry period. Concentrates were not supplied in experiment $B$ to animals of group LE. Concentrate intake in experiment $C$ was lower for group HD, but this difference was not significant.

NEL intake was relatively low during the dry period and continuously increased after parturition during the 3 months of the study, but there were significant differences between the groups only in experiment B (Table 1; Figure 2). NEL balances were positive before, but negative after parturition, particularly in early lactation. They were more negative for group LE than for group $\mathrm{HE}$ and tended to be lower for group $\mathrm{HD}$ than for group LD $(P<0.05$ for the 1 st month of lactation).

AP intake was relatively low during the dry period. It increased during lactation, in groups $\mathrm{HE}$ and LD particularly during the 1st month and there were signficant differences $(P<0.05)$ between groups LE and HE, as well as between LD and HD (Table 1). AP balances were positive before parturition and became transiently negative during the 1st month of lactation in groups LE and LD and during the first 8 weeks of lactation in group HD. AP balances were significantly lower in group LE throughout the study than in group $\mathrm{HE}$ and in group HD during the first 8 weeks post partum compared with group LD $(P<0.05)$.

Milk yield (FCM) increased rapidly during the first 2 to 4 weeks and was maximal during the 2nd month of lactation. It was significantly higher during the study in group HE than LE $(P<0.05$ for the 2 nd and 3rd month of lactation), but comparable in groups LD and HD. Milk fat content decreased during the 1st month of lactation, but was not significantly different between experimental groups. Milk protein content transiently decreased during the 2 nd month of lactation, but was lower in group LE than in group $\mathrm{HE}(P<0.05$ during the 2nd and 3rd month of lactation) and in group HD than in group LD (not significantly). Lactose content was numerically lower during the 1st month of lactation, but there were no significant differences between the groups.

Plasma concentrations of glucose transiently decreased during the 1st month of lactation (Table 2; Figure 3). Glucose levels were significantly lower during the first 2 months of lactation in group LE compared with group $\mathrm{HE} \quad(P<0 \cdot 05)$. NEFA concentration reversibly increased during the 1st month of 
lactation, particularly in group LE, with significant differences between groups $\mathrm{HE}$ and LE for the first 2 months of lactation. Ketone bodies (acetoacetate plus $\beta$-hydroxybutyrate) increased after parturition. The increase was highest and significantly greater in group LE than in group $\mathrm{HE}(P<0.05$ for the first 2 months of lactation), but only numerically greater for group HD than for group LD.

Plasma concentrations of protein were higher during lactation than during the dry period in experiment $B$, but not in experiment $\mathrm{C}$ and levels were significantly higher in group HE than in group LE during the whole study (Table 2, $P<0.05$ ). Albumin was increased during lactation compared with the dry period. Levels were significantly lower in group LE than in group $\mathrm{HE}$ for the first 2 months of lactation $(P<0 \cdot 05)$. Urea transiently decreased in group LE and in group $\operatorname{HD}(P<0.05)$, but increased in groups $\mathrm{HE}$ and $\mathrm{LD}(P<0.05)$ during lactation. Levels were lower in group LE than in group $\operatorname{HE~}(P<0.05)$ and in group HD than in group LD $(P<0.05$ for the first 8 weeks after parturition).

Levels of $\mathrm{SmC}$ were highest during the dry period (Table 2; Figure 4). SmC sharply decreased at parturition and remained lowest during the 1st month of lactation in all experimental groups and then slowly increased again. SmC concentrations were always lower

TABLE 1

Dry matter (DM) (basic ration (BR) and concentrates $(C)$ ), net energy lactation (NEL) and crude protein (CP) intakes and absorbable protein (AP) intakes and balances, fat-corrected milk yield (FCM) and milk composition during the dry period (last 2 weeks before parturition) and during the first 3 months of lactation.

Experiment B

\begin{tabular}{|c|c|c|c|c|c|c|c|c|c|}
\hline & & & & & & & & & \\
\hline & & & & & & Weeks o & ictation & & \\
\hline No of animals & $\begin{array}{l}\text { HE } \\
\text { LE }\end{array}$ & Dry & & & & $\begin{array}{rl}5 & t \\
& 1 \\
& 1\end{array}$ & & $\begin{array}{r}9 \text { to } \\
\\
\\
\\
\\
\end{array}$ & \\
\hline & & Mean & s.e. & Mean & s.e. & Mean & s.e. & Mean & s.e. \\
\hline Body weight & $\mathrm{HE}$ & 711 & $11^{\mathrm{a}}$ & 640 & $10^{\mathrm{b}}$ & 617 & $10^{c}$ & 614 & $11^{\circ}$ \\
\hline$(\mathrm{kg})$ & LE & 681 & $19^{a}$ & $592^{*}$ & $18^{\mathrm{b}}$ & $566^{*}$ & $16^{\mathrm{c}}$ & $562^{*}$ & $16^{\mathrm{d}}$ \\
\hline DM intake & $\mathrm{HE}$ & $12 \cdot 7$ & $0.5^{3}$ & $15 \cdot 1$ & $0 \cdot 6^{\mathrm{b}}$ & $17 \cdot 9$ & $0.6^{\mathrm{C}}$ & $18 \cdot 3$ & $0.5^{c}$ \\
\hline BR (kg/day) & $\mathrm{LE}$ & $13 \cdot 2$ & $0.9^{a}$ & $15 \cdot 7$ & $0 \cdot 6^{\mathrm{b}}$ & $17 \cdot 6$ & $0.7^{\mathrm{c}}$ & 18.9 & $\left(0 \cdot 6^{\mathrm{c}}\right.$ \\
\hline DM intake & $\mathrm{HE}$ & $2 \cdot 6$ & $0 \cdot 1^{\mathrm{a}}$ & $3 \cdot 7$ & $0 \cdot 3^{\mathrm{b}}$ & $3 \cdot 3$ & $0.3^{\mathrm{b}}$ & $2 \cdot 6$ & $0 \cdot 4^{\mathrm{ah}}$ \\
\hline $\mathrm{C}(\mathrm{kg} /$ day $)$ & LE & $0^{*}$ & 0 & $0^{*}$ & 0 & $0^{*}$ & 0 & $0^{*}$ & 0 \\
\hline NEL intake & $\mathrm{HE}$ & 93 & $3^{\mathrm{a}}$ & 117 & $2^{b}$ & 132 & $2^{c}$ & 132 & $3^{c}$ \\
\hline (MJ/day) & LE & $75^{*}$ & $4^{4}$ & $92^{*}$ & $3^{b}$ & $105^{*}$ & $4^{c}$ & $115^{*}$ & 4 \\
\hline NEL balance & $\mathrm{HE}$ & 34 & $3^{4}$ & -7 & $3^{\mathrm{b}}$ & 0 & $3^{b}$ & 7 & $1^{c}$ \\
\hline (MJ/day) & LE & $18^{*}$ & $4^{a}$ & $-23^{*}$ & $3^{b}$ & -10 & $2^{c}$ & 4 & $2^{d}$ \\
\hline $\mathrm{CP}$ intake & $\mathrm{HE}$ & 2083 & $64^{\mathrm{a}}$ & 3514 & $86^{\text {bd }}$ & 3643 & $96^{b c}$ & 3278 & $94^{d}$ \\
\hline (g/day) & LE & $1735^{*}$ & $94^{a}$ & $1984^{*}$ & $71^{\mathrm{ab}}$ & $2101^{*}$ & $81^{\mathrm{h}}$ & $2630^{*}$ & $69^{\circ}$ \\
\hline $\mathrm{AP}$ intake & $\mathrm{HE}$ & 1480 & $45^{\mathrm{a}}$ & $217 i$ & $43^{\mathrm{b}}$ & 2419 & $53^{\mathrm{c}}$ & 2253 & $63^{b}$ \\
\hline (g/day) & LE & $1167^{*}$ & $70^{\mathrm{a}}$ & $1392^{*}$ & $48^{\mathrm{b}}$ & $1548^{*}$ & $61^{\circ}$ & $1776^{*}$ & $58^{4}$ \\
\hline AP balance & $\mathrm{HE}$ & 828 & $44^{\mathrm{a}}$ & 400 & $39^{\mathrm{h}}$ & 613 & $27^{\circ}$ & 518 & $44^{d}$ \\
\hline (g/day) & LE & $529^{*}$ & $66^{\mathrm{a}}$ & $-209^{*}$ & $39^{\mathrm{b}}$ & $49^{*}$ & $28^{\mathrm{c}}$ & $301 *$ & $33^{b x}$ \\
\hline FCM & $\mathrm{HE}$ & & & $27 \cdot 0$ & $1 \cdot 2$ & $30 \cdot 6$ & $1 \cdot 3$ & $28 \cdot 1$ & $1 \cdot 1$ \\
\hline$(\mathrm{kg} / \mathrm{day})$ & LE & & & 24.9 & $1 \cdot 0$ & $25 \cdot 7^{*}$ & $1 \cdot 0$ & $24 \cdot 5^{*}$ & $1 \cdot 1$ \\
\hline Milk fat & $\mathrm{HE}$ & & & $42 \cdot 4$ & $1 \cdot 3$ & $40 \cdot 0$ & $1 \cdot 1$ & $40 \cdot 2$ & $1 \cdot 0$ \\
\hline$(\mathrm{g} / \mathrm{l})$ & LE & & & $44 \cdot 2$ & $1 \cdot 3^{\mathrm{a}}$ & $40 \cdot 4$ & $0.6^{\mathrm{h}}$ & $40 \cdot 3$ & $0 \cdot 8^{b}$ \\
\hline Milk protein & $\mathrm{HE}$ & & & $34 \cdot 0$ & $0 \cdot 8^{\mathrm{a}}$ & $30 \cdot 5$ & $0.5^{\mathrm{b}}$ & 31.6 & $0.5^{b}$ \\
\hline$(\mathrm{g} / \mathrm{l})$ & LE & & & 33.7 & $0 \cdot 6^{\mathrm{a}}$ & $29 \cdot 1^{*}$ & $0 \cdot 3^{h}$ & $29.9^{*}$ & $0.3^{c}$ \\
\hline Milk lactose & $\mathrm{HE}$ & & & $49 \cdot 6$ & 0.4 & $50 \cdot 8$ & $0 \cdot 4$ & $50 \cdot 5$ & $0 \cdot 3$ \\
\hline$(\mathrm{g} / \mathrm{l})$ & $\mathrm{LE}$ & & & 48.9 & 0.4 & $50 \cdot 0$ & $0 \cdot 4$ & $49 \cdot 8$ & 0.3 \\
\hline
\end{tabular}


Experiment $\mathrm{C}$

\begin{tabular}{|c|c|c|c|c|c|c|c|c|c|}
\hline \multirow{3}{*}{ No of animals } & \multirow{3}{*}{$\begin{array}{l}\text { LD } \\
\text { HD }\end{array}$} & & & \multicolumn{6}{|c|}{ Weeks of lactation } \\
\hline & & \multicolumn{2}{|c|}{$\begin{array}{c}\text { Dry period } \\
10 \\
9\end{array}$} & \multicolumn{2}{|c|}{$\begin{array}{r}1 \text { to } 4 \\
10 \\
9\end{array}$} & \multicolumn{2}{|c|}{$\begin{array}{c}5 \text { to } 8 \\
10 \\
9\end{array}$} & \multicolumn{2}{|c|}{$\begin{array}{c}9 \text { to } 12 \\
10 \\
9\end{array}$} \\
\hline & & Mean & s.e. & Mean & s.e. & Mean & s.e. & Mean & s.e. \\
\hline $\begin{array}{l}\text { Body weight } \\
(\mathrm{kg})\end{array}$ & $\begin{array}{l}\text { LD } \\
\text { HD }\end{array}$ & $\begin{array}{l}742 \\
791\end{array}$ & $\begin{array}{l}18^{\mathrm{a}} \\
16^{\mathrm{a}}\end{array}$ & $\begin{array}{l}671 \\
707\end{array}$ & $\begin{array}{l}18^{\mathrm{b}} \\
12^{\mathrm{b}}\end{array}$ & $\begin{array}{l}663 \\
698\end{array}$ & $\begin{array}{l}17^{b} \\
14^{b}\end{array}$ & $\begin{array}{l}666 \\
694\end{array}$ & $\begin{array}{l}18^{\mathrm{b}} \\
14^{\mathrm{b}}\end{array}$ \\
\hline DM intake & LD & $11 \cdot 5$ & $0.4^{4}$ & $12 \cdot 8$ & $0 \cdot 4^{\mathrm{b}}$ & $13 \cdot 5$ & $0.5^{\mathrm{b}}$ & $13 \cdot 7$ & $0 \cdot 4^{\text {ah }}$ \\
\hline BR (kg/day) & $\mathrm{HD}$ & $11 \cdot 8$ & $0.4^{a}$ & $13 \cdot 2$ & $0.6^{\mathrm{ab}}$ & $14 \cdot 2$ & $0.6^{\mathrm{b}}$ & $13 \cdot 8$ & $0.4^{b}$ \\
\hline DM intake & LD & $1 \cdot 3$ & $0 \cdot 1^{\mathrm{a}}$ & $4 \cdot 2$ & $0.4^{b}$ & $6 \cdot 5$ & $0.9^{\mathrm{b}}$ & $6 \cdot 7$ & $0.9^{b}$ \\
\hline C (kg/day) & HD & $1 \cdot 3$ & $0 \cdot 1^{\text {a }}$ & $3 \cdot 2$ & $0.4^{\mathrm{b}}$ & $5 \cdot 0$ & $0.7^{\mathrm{bc}}$ & $6 \cdot 5$ & $0 \cdot 8^{\mathrm{c}}$ \\
\hline NEL intake & LD & 79 & $3^{\mathrm{a}}$ & 109 & $2^{b}$ & 132 & $2^{c}$ & 136 & $3^{c}$ \\
\hline (MJ/day) & HD & 81 & $2^{\mathrm{a}}$ & 104 & $2^{\mathrm{b}}$ & 125 & $2^{\mathrm{c}}$ & 134 & $3^{c}$ \\
\hline NEL balance & LD & 20 & $3^{\mathrm{a}}$ & -25 & $2^{b}$ & -15 & $2^{c}$ & -2 & $1^{\mathrm{d}}$ \\
\hline (MJ/day) & HD & 19 & $2^{a}$ & $-32^{*}$ & $2^{b}$ & -18 & $2^{c}$ & -5 & $1^{\mathrm{d}}$ \\
\hline $\mathrm{CP}$ intake & LD & 1585 & $70^{\mathrm{a}}$ & 2590 & $92^{\mathrm{b}}$ & 3029 & $143^{c}$ & 2671 & $135^{\mathrm{bc}}$ \\
\hline (g/day) & HD & 1618 & $37^{\mathrm{a}}$ & $2099^{*}$ & $46^{\mathrm{b}}$ & $2444^{*}$ & $89^{c}$ & $2656^{*}$ & $102^{c}$ \\
\hline AP intake & LD & 1200 & $50^{\mathrm{a}}$ & 1843 & $51^{\mathrm{b}}$ & 2188 & $29^{c}$ & 2052 & $42^{\mathrm{d}}$ \\
\hline (g/day) & HD & $1233^{*}$ & $26^{\mathrm{a}}$ & $1588^{*}$ & $20^{b}$ & $1876^{*}$ & $47^{c}$ & 2030 & $49^{c}$ \\
\hline AP balance & LD & 534 & $45^{a}$ & -155 & $17^{\mathrm{b}}$ & 128 & $19^{c}$ & 95 & $18^{\mathrm{c}}$ \\
\hline (g/day) & HD & 545 & $28^{a}$ & $-342^{*}$ & $29^{\mathrm{b}}$ & $-71^{*}$ & $10^{\mathrm{c}}$ & 110 & $17^{\mathrm{d}}$ \\
\hline $\mathrm{FCM}$ & LD & & & $30 \cdot 4$ & $1 \cdot 3^{a}$ & $34 \cdot 5$ & $0 \cdot 6^{b}$ & $31 \cdot 6$ & $0.7^{\mathrm{a}}$ \\
\hline (kg/day) & HD & & & $30 \cdot 7$ & 0.9 & $33 \cdot 0$ & $1 \cdot 1$ & $31 \cdot 6$ & $1 \cdot 1$ \\
\hline Milk fat & LD & & & $42 \cdot 7$ & $1 \cdot 4^{\mathrm{a}}$ & $40 \cdot 2$ & $0.9^{b}$ & $40 \cdot 9$ & $1 \cdot 0^{\mathrm{ab}}$ \\
\hline$(\mathrm{g} / \mathrm{l})$ & HD & & & $42 \cdot 6$ & $1 \cdot 6$ & $41 \cdot 1$ & $1 \cdot 8$ & $41 \cdot 4$ & $2 \cdot 1$ \\
\hline Milk protein & LD & & & $36 \cdot 2$ & $0.9^{a}$ & $31 \cdot 6$ & $0 \cdot 4^{\mathrm{b}}$ & $32 \cdot 7$ & $0.7^{\mathrm{b}}$ \\
\hline$(\mathrm{g} / \mathrm{l})$ & HD & & & $33 \cdot 6$ & $0.7^{\mathrm{a}}$ & $30 \cdot 6$ & $0.6^{b}$ & $31 \cdot 5$ & $0.7^{\mathrm{ab}}$ \\
\hline Milk lactose & LD & & & $49 \cdot 2$ & 0.5 & $50 \cdot 5$ & 0.3 & $49 \cdot 7$ & $0 \cdot 3$ \\
\hline$(\mathrm{g} / \mathrm{l})$ & HD & & & $49 \cdot 4$ & $0-7$ & $50 \cdot 6$ & $0 \cdot 3$ & $50 \cdot 3$ & 0.4 \\
\hline
\end{tabular}

a,b,c Different superscripts indicate significant differences between dry period, week 1 to 4 , week 5 to 8 or 9 to 12 of lactation $(P<0 \cdot 05)$.

* Significant difference between groups LE and HE and LD and HD $(P<0.05)$.

in group LE than in group HE $(P<0.05$ for the dry period and the 1st month of lactation), but similar in groups LD and HD.

In contrast to SmC, STH increased after parturition, with highest levels reached during the 1st month of lactation $(P<0.05)$. STH was significantly higher in group LE than in group $\mathrm{HE}$ during lactation $(P<0.05)$, but similar in groups LD and HD.

Levels of IRI, as those of SmC, were highest during the dry period and rapidly decreased after parturition, remained low during the 1st month of lactation and then increased again. IRI levels were lower in group LE than in group $\mathrm{HE}(P<0.05$ during the first 2 months of lactation), but similar in groups $\mathrm{HD}$ and $\mathrm{LD}$.

Concentrations of $\mathrm{T}_{3}$ transiently decreased after parturition in experiment $\mathrm{B}$, particularly in group LE, while they increased continuously in experiment $C$. Levels of $T_{3}$ were always lower in group LE than group HE (not significantly), but comparable in groups $\mathrm{LD}$ and $\mathrm{HD} . \mathrm{T}_{4}$ levels transiently decreased in all groups after parturition, but there were significant differences only for the 1st month of lactation between groups $\mathrm{HE}$ and LE.

SmC showed highest positive correlations $(P<0.05)$ with energy (Figure 5) and protein balances, with glucose, IRI, $T_{4}$ and $T_{3}$ in both experiments (Table 3). Negative energy balances were related to low concentrations of SmC. Elevated $\mathrm{SmC}$ values were found if energy balances were positive. Correlations with AP balances were higher in experiment C. Energy and protein balances were closely related in both experiments $(r=0.83)$, but 
partial correlations revealed only negligible effects of AP balance (not shown). There were negative correlations of $\mathrm{SmC}$ with $\mathrm{FCM}$, ketone bodies and STH.

Effects of different energy and protein intake and of crystalline fat on energy and protein balances, milk yield and composition, metabolites and hormones $(S m C, S T H, I R I$, $T_{3}$ and $T_{4}$ ) during a 24-h period (experiment D)

Levels of $\mathrm{SmC}$ did not change during the 24-h period (Figure 6). In contrast, IRI and STH exhibited marked diurnal variations, mainly due to an increase in response to concentrate feeding (at $06.00 \mathrm{~h}$ and $14.30 \mathrm{~h}$ ).

Body weight tended to be higher in groups $\mathrm{HE}$ and $\mathrm{CF}$ than in group LE (Table 4).
Intake of $\mathrm{BR}$ was similar, whereas $\mathrm{C}$, NEL and AP intake were lowest in group LE and highest in group CF. NEL and AP balances were most markedly negative in group LE, but positive in group $\mathrm{CF}$.

FCM and milk lactose were similar in groups $\mathrm{LE}, \mathrm{HE}$ and $\mathrm{CF}$, whereas milk fat and protein were highest in group LE and lowest in group CF $(P<0 \cdot 05)$.

Glucose levels were lowest in group LE and highest in group CF, whereas the reverse was found for NEFA, ketone bodies and urea, while protein and albumin levels were not consistently changed.

$\mathrm{SmC}$, IRI, $\mathrm{T}_{3}$ and $\mathrm{T}_{4}$ were numerically or significantly lower in group LE than in groups $\mathrm{HE}$ or CF. In contrast, STH was highest in group LE and lowest in group CF.

TABLE 2

Blood metabolites and hormones during the dry period (last 2 weeks before parturition) and during the first 3 months of lactation

Experiment B

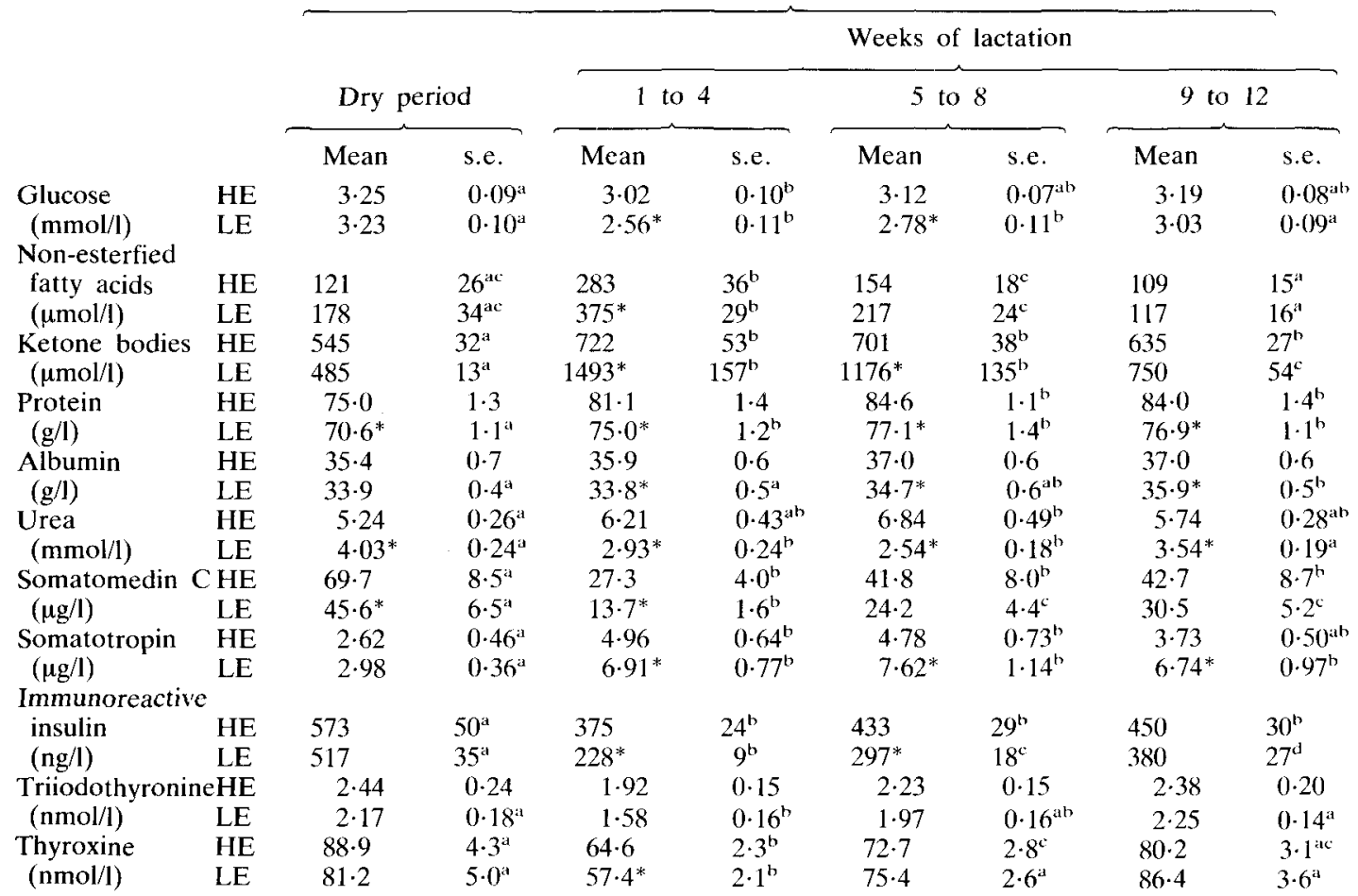


Experiment $\mathrm{C}$

\begin{tabular}{|c|c|c|c|c|c|c|c|c|c|}
\hline & & & & & & & & & \\
\hline & & & & & & Weeks o & lactation & & \\
\hline & & \multicolumn{2}{|c|}{ Dry period } & \multicolumn{2}{|c|}{1 to 4} & \multicolumn{2}{|c|}{5 to 8} & \multicolumn{2}{|c|}{9 to 12} \\
\hline & & Mean & s.e. & Mean & s.e. & Mean & s.e. & Mean & s.e. \\
\hline Glucose & $\mathrm{HE}$ & $3 \cdot 08$ & $0 \cdot 09^{a}$ & $2 \cdot 62$ & $0 \cdot 05^{\mathrm{b}}$ & $2 \cdot 61$ & $0 \cdot 09^{\mathrm{b}}$ & $2 \cdot 84$ & $0 \cdot 04^{c}$ \\
\hline$(\mathrm{mmol} / \mathrm{l})$ & $\mathrm{LE}$ & $3 \cdot 03$ & $0.05^{\mathrm{a}}$ & $2 \cdot 71$ & $0 \cdot 08^{b}$ & $2 \cdot 68$ & $0 \cdot 06^{\mathrm{b}}$ & $2 \cdot 86$ & $0.06^{\mathrm{ab}}$ \\
\hline \multicolumn{10}{|l|}{ Non-esterfied } \\
\hline fatty acids & $\mathrm{HE}$ & 165 & $17^{\mathrm{ac}}$ & 280 & $17^{\mathrm{b}}$ & 193 & $16^{a}$ & 148 & $6^{\mathrm{c}}$ \\
\hline$(\mu \mathrm{mol} / \mathrm{l})$ & LE & 189 & $21^{a}$ & 244 & $24^{\mathrm{a}}$ & 197 & $19^{a}$ & 135 & $9^{b}$ \\
\hline \multirow{2}{*}{$\begin{array}{l}\text { Ketone bodies } \\
(\mu \mathrm{mol} / \mathrm{l})\end{array}$} & $\mathrm{HE}$ & 760 & $81^{a}$ & 1191 & $138^{\mathrm{b}}$ & 1757 & $187^{b}$ & 1271 & $175^{\mathrm{b}}$ \\
\hline & LE & 849 & $96^{\mathrm{a}}$ & 1469 & $159^{h}$ & 1924 & $268^{\mathrm{b}}$ & 1460 & $132^{\mathrm{b}}$ \\
\hline \multirow{2}{*}{$\begin{array}{l}\text { Protein } \\
(\mathrm{g} / \mathrm{l})\end{array}$} & $\mathrm{HE}$ & $70 \cdot 6$ & $2 \cdot 2$ & 69.9 & 0.9 & 71.9 & $1 \cdot 0$ & $71 \cdot 6$ & 0.9 \\
\hline & LE & $69 \cdot 0$ & $1 \cdot 5$ & $69 \cdot 8$ & 0.6 & $70 \cdot 0$ & 0.5 & $70 \cdot 5$ & 0.7 \\
\hline \multirow{2}{*}{$\begin{array}{l}\text { Albumin } \\
(\mathrm{g} / \mathrm{l})\end{array}$} & $\mathrm{HE}$ & $34 \cdot 9$ & $0 \cdot 9^{a}$ & 36.9 & $0 \cdot 3^{a}$ & $38 \cdot 1$ & $0 \cdot 3^{\mathrm{b}}$ & 37.9 & $0 \cdot 3^{\mathrm{b}}$ \\
\hline & LE & $35 \cdot 3$ & $0 \cdot 3^{a}$ & $37 \cdot 4$ & $0 \cdot 3^{\mathrm{b}}$ & $37 \cdot 3$ & $0 \cdot 3^{b}$ & $38 \cdot 3$ & $0 \cdot 3^{b}$ \\
\hline \multirow{2}{*}{$\begin{array}{l}\text { Urea } \\
(\mathrm{mmol} / \mathrm{l})\end{array}$} & $\mathrm{HE}$ & $3 \cdot 32$ & $0.33^{a}$ & $4 \cdot 46$ & $0 \cdot 16^{6}$ & $4 \cdot 77$ & $0.09^{\mathrm{b}}$ & $3 \cdot 37$ & $0 \cdot 11^{\mathrm{a}}$ \\
\hline & LE & $4 \cdot 27$ & $0 \cdot 29^{\mathrm{a}}$ & $3 \cdot 24^{*}$ & $0 \cdot 11^{b}$ & $3 \cdot 25^{*}$ & $0 \cdot 13^{b}$ & 3.67 & $0 \cdot 11^{\mathrm{a}}$ \\
\hline \multirow{2}{*}{$\begin{array}{l}\text { Somatomedin } \\
(\mu \mathrm{g} / \mathrm{l})\end{array}$} & $\mathrm{CHE}$ & $67 \cdot 2$ & $16 \cdot 2^{\mathrm{a}}$ & $22 \cdot 2$ & $2 \cdot 7^{\mathrm{b}}$ & $26 \cdot 3$ & $2 \cdot 3^{b}$ & $30 \cdot 7$ & $2 \cdot 9^{b}$ \\
\hline & LE & $64 \cdot 5$ & $11 \cdot 2^{\mathrm{a}}$ & $19 \cdot 2$ & $1 \cdot 5^{\mathrm{b}}$ & $25 \cdot 5$ & $1 \cdot 6^{c}$ & $32 \cdot 5$ & $2 \cdot 0^{\mathrm{d}}$ \\
\hline \multirow{2}{*}{$\begin{array}{l}\text { Somatotropin } \\
(\mu \mathrm{g} / \mathrm{l})\end{array}$} & $\mathrm{HE}$ & 1.87 & $0 \cdot 33^{\mathrm{a}}$ & $4 \cdot 46$ & $0 \cdot 35^{\mathrm{b}}$ & $4 \cdot 03$ & $0.43^{b}$ & 3.34 & $0 \cdot 31^{\mathrm{b}}$ \\
\hline & LE & 1.90 & $0 \cdot 32^{\mathrm{a}}$ & $4 \cdot 98$ & $0 \cdot 27^{\mathrm{b}}$ & $4 \cdot 34$ & $0 \cdot 59^{\mathrm{bc}}$ & $2 \cdot 84^{*}$ & $0 \cdot 28^{\mathrm{ac}}$ \\
\hline \multicolumn{10}{|l|}{ Immunoreactive } \\
\hline insulin & HE & 681 & $144^{a}$ & 318 & $27^{\mathrm{b}}$ & 497 & $44^{a}$ & 559 & $47^{\mathrm{a}}$ \\
\hline$(\mathrm{ng} / \mathrm{l})$ & LE & 737 & $152^{a}$ & 336 & $34^{b}$ & 527 & $58^{a}$ & 552 & $49^{a}$ \\
\hline \multicolumn{2}{|c|}{ Triiodothyronine HE } & $2 \cdot 22$ & $0 \cdot 09^{\mathrm{a}}$ & $2 \cdot 29$ & $0 \cdot 06^{\mathrm{a}}$ & $2 \cdot 75$ & $0 \cdot 04^{\mathrm{b}}$ & $3 \cdot 01$ & $0 \cdot 09^{c}$ \\
\hline$(\mathrm{nmol} / \mathrm{l})$ & LE & $2 \cdot 37$ & $0 \cdot 17^{\mathrm{a}}$ & $2 \cdot 41$ & $0 \cdot 10^{\mathrm{ac}}$ & $2 \cdot 81$ & $0 \cdot 13^{\mathrm{hc}}$ & 2.95 & $0 \cdot 06^{\mathrm{b}}$ \\
\hline \multirow{2}{*}{$\begin{array}{c}\text { Thyroxine } \\
(\mathrm{nmol} / \mathrm{l})\end{array}$} & $\mathrm{HE}$ & $77 \cdot 6$ & $3 \cdot 6^{\mathrm{ac}}$ & $66 \cdot 7$ & $2 \cdot 3^{b}$ & $74 \cdot 2$ & $1 \cdot 4^{a}$ & $79 \cdot 4$ & $1 \cdot 8^{c}$ \\
\hline & LE & $89 \cdot 6$ & $6 \cdot 1^{a}$ & $66 \cdot 3$ & $1 \cdot 2^{b}$ & $72 \cdot 7$ & $1 \cdot 7^{\mathrm{c}}$ & $80 \cdot 8$ & $1 \cdot 5^{a}$ \\
\hline
\end{tabular}

\section{DISCUSSION}

In the study lasting over the entire lactation, energy and protein balances were always positive, because of a relatively low milk yield. In further experiments, in which high-yielding cows were used, energy and protein balances became markedly negative in the first months of lactation, even when given high amounts of concentrates. Only with the feeding of crystalline fat were calculated energy and protein balances positive after parturition.

FCM yield was either unaffected or only slightly reduced in cows consciously underfed with energy and protein. Marked energy deficiency was associated with decreased milk protein and in part with increased milk fat, marked protein deficiency with decreased milk protein. Feeding high amounts of crystalline fat as in this study caused lowered milk fat and protein concentration.
As shown previously (Blum et al., 1985a; Kunz et al., 1985; Mills, Beitz and Young, 1986), negative energy balances were typically characterized by low glucose and high NEFA and ketone body levels, suggesting insufficient gluconeogenesis, enhanced fat mobilization and ketogenesis. Negative protein balances were typically characterized by low urea concentrations, whereas an oversupply of protein when energy balances were negative was followed by elevated urea concentrations. Combined low energy and protein intake led to low circulating urea, partially low albumin and protein and high NEFA and ketone body concentrations (Oldham, Broster, Napper and Siviter, 1979; Oltner and Wiktorsson, 1983; Clement, 1988). On the other hand, feeding crystalline fat improved energy supply and was characterized by relatively high blood glucose, relatively low levels of NEFA and ketone bodies (Blum et al., 1985a). 

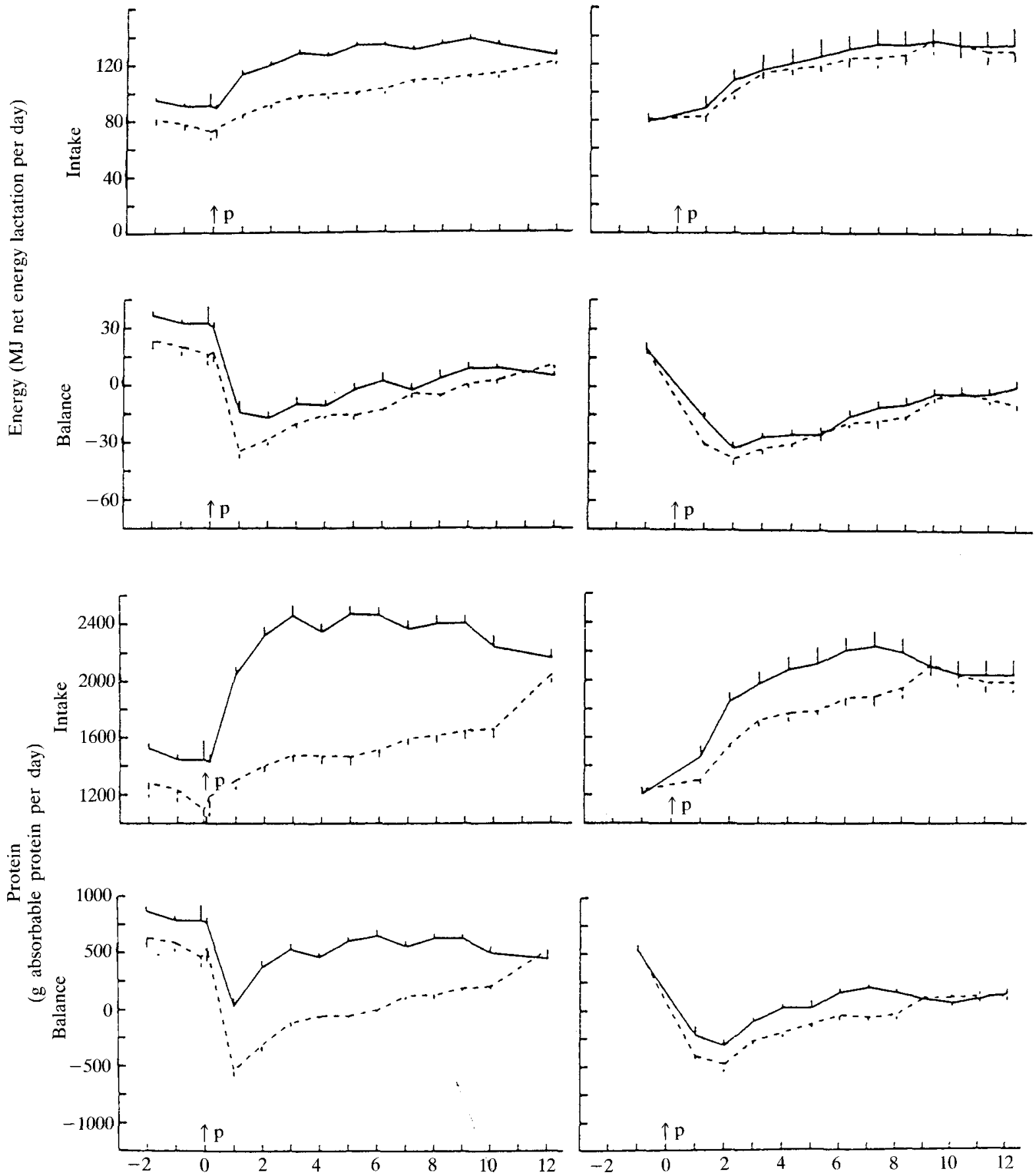

Weeks from parturition

FIG. 2. Energy and protein intake and balances of experiments B and C (on left and right side, respectively). Each point represents the mean \pm s.e. of a 7-day period. - , groups HE and LD, respectively - . - groups LE and $H D$, respectively. $P=$ parturition. 

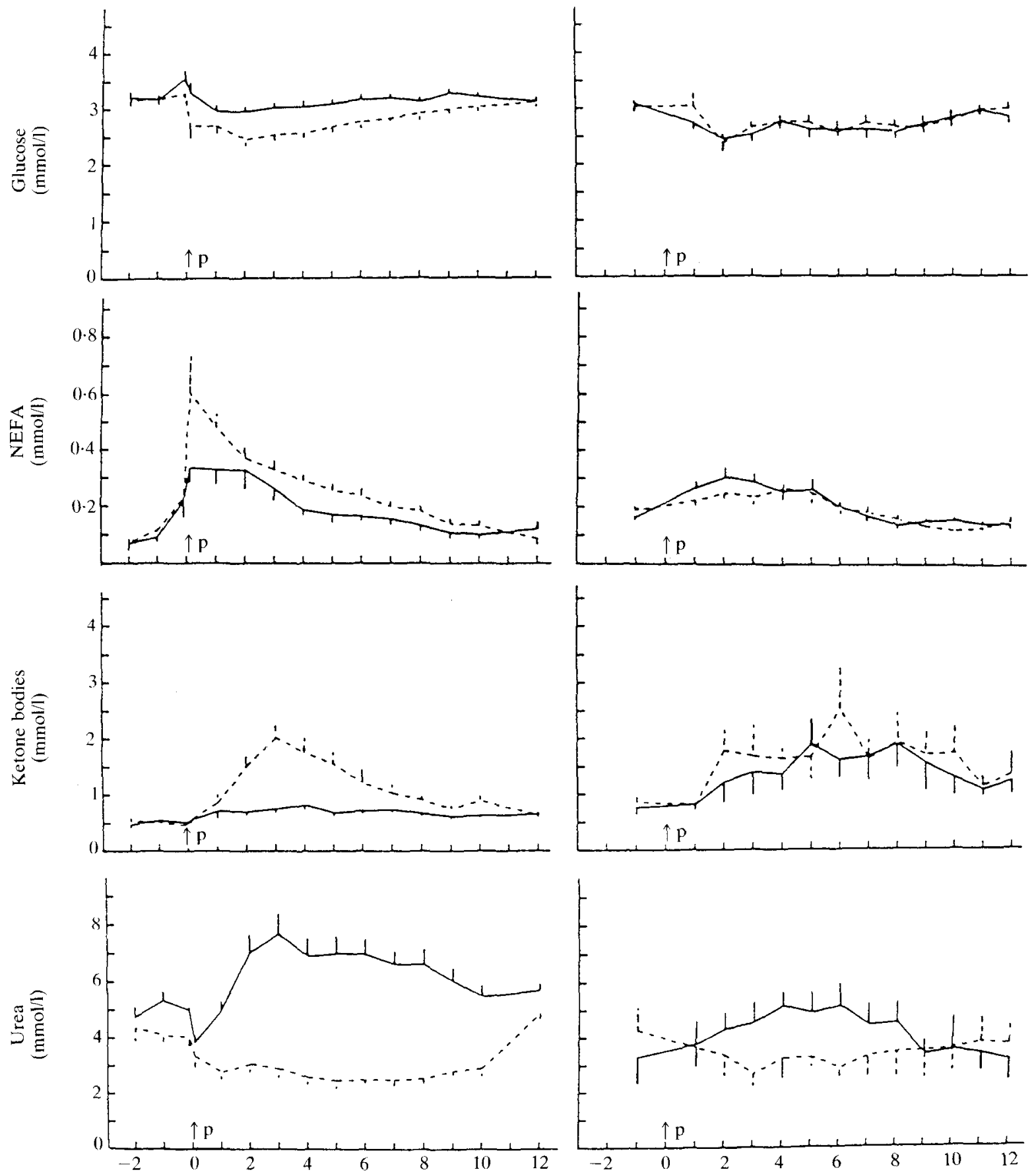

Weeks from parturition

Fig. 3. Blood levels of glucose, non-esterified fatty acid (NEFA), ketone bodies and urea (experiments B and C). For further details see legend to Figure 2. 

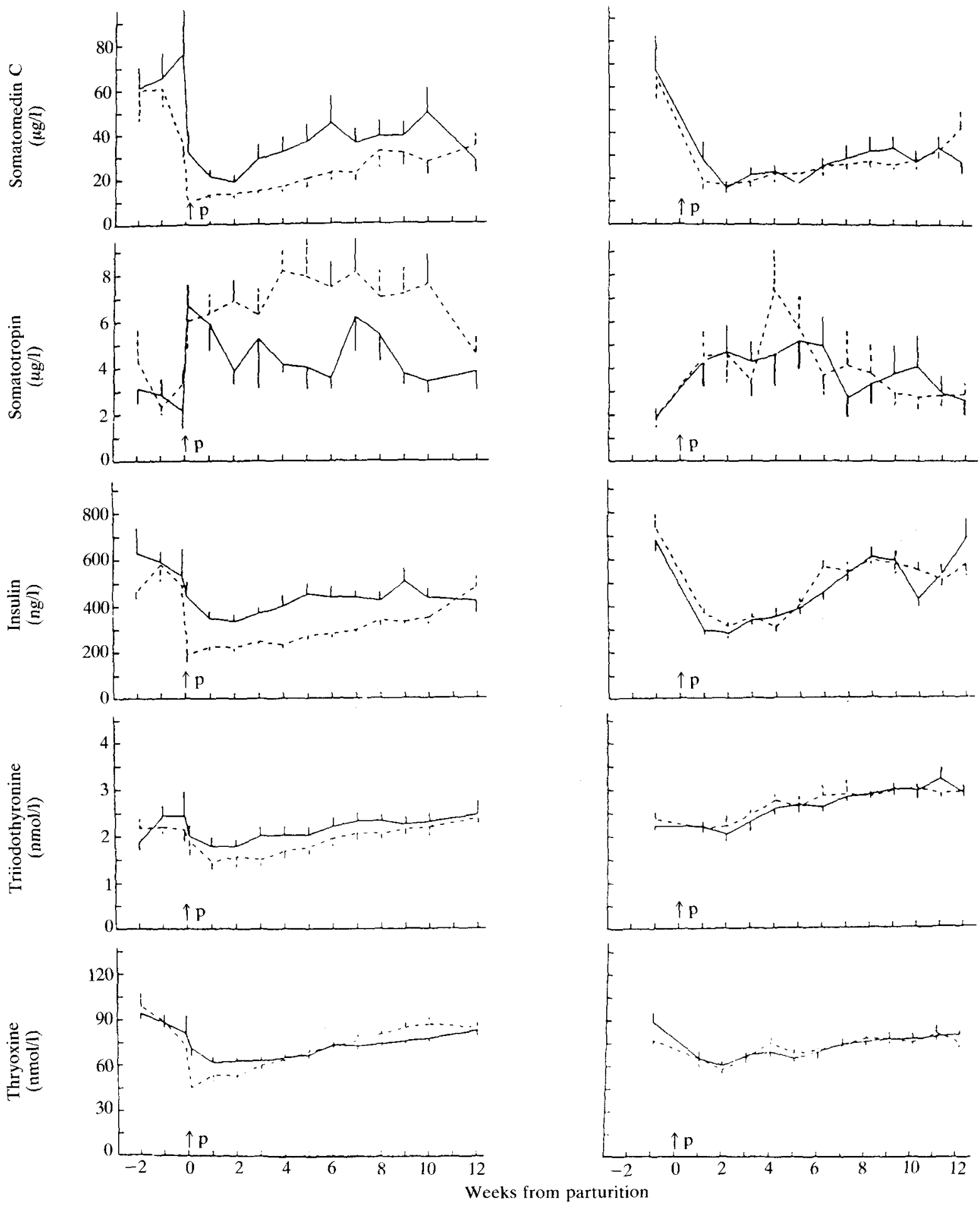

Fig. 4. Blood levels of somatomedin C, somatotropin, immunoreactive insulin, triiodothyronine and thyroxine (experiments $\mathrm{B}$ and $\mathrm{C}$ ). For further details see legend to Figure 2. 


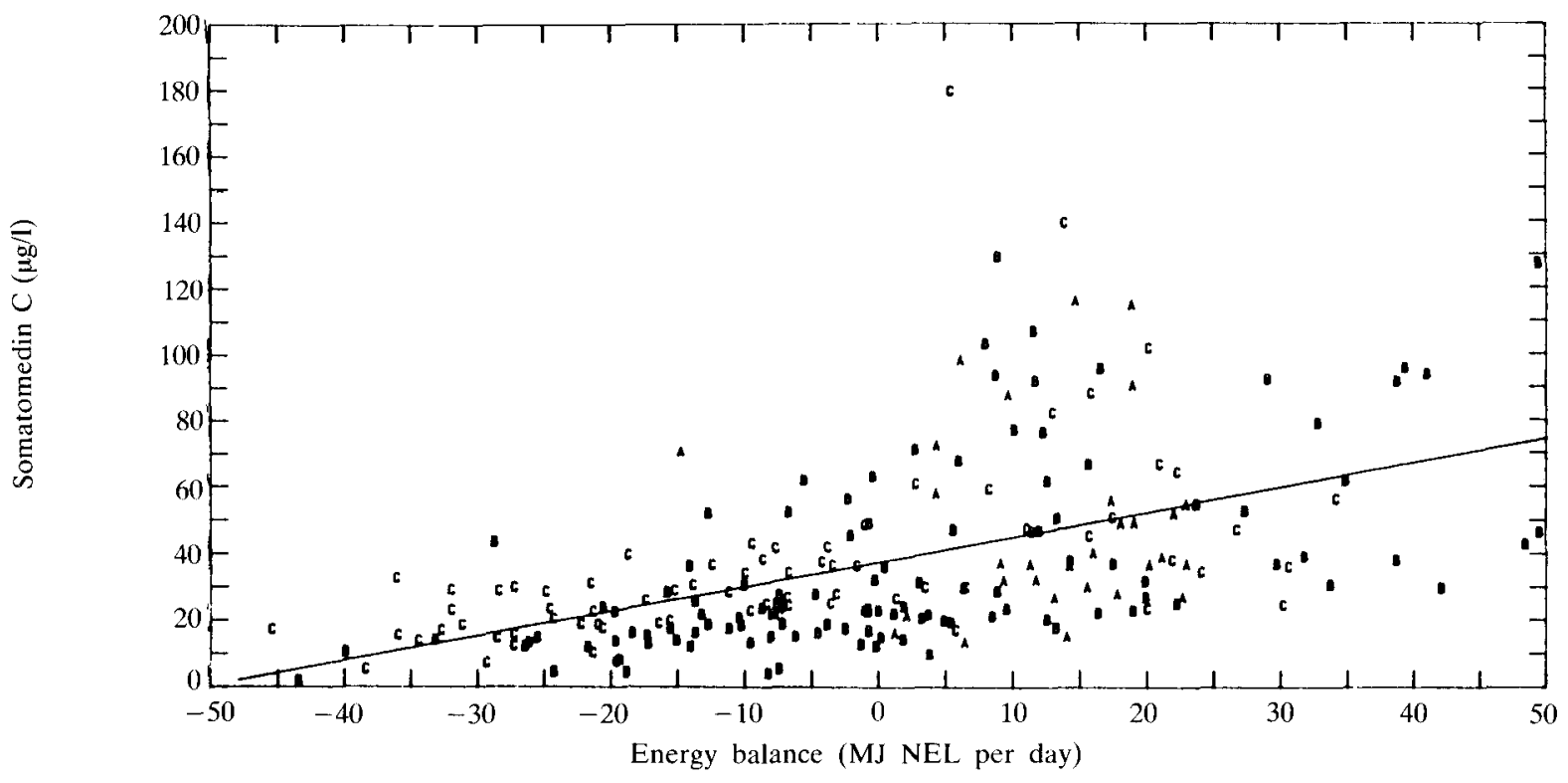

FIG. 5. Relationship between somatomedin $C$ and energy balances from the dry period (2 weeks approx.) up to the 12 th week of lactation. Each point represents the mean of 4 weeks for each animal from experiments A, B and C.

TABLE 3

Experiments $B$ and $C$ : correlationt of somatomedin $C$ with various measurements

Experiment

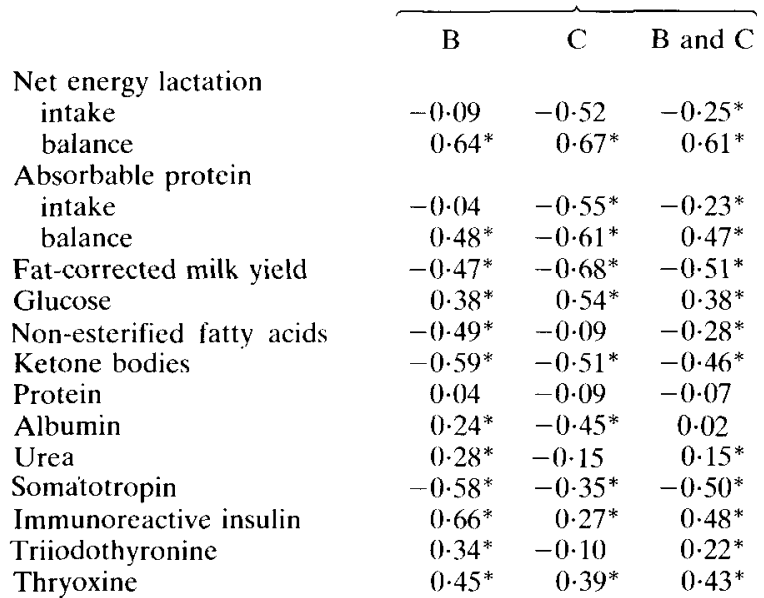

+ Correlations are calculated for each experiment over periods and animals. Degrees of freedom were: 74 for $B$, 118 for $C$ and 194 for $B$ and $C$.
Somatomedin $\mathrm{C}$ was very stable during the $24 \mathrm{~h}$ studied (Figure 6). In particular, SmC levels did not change in response to food intake. This is in accordance with studies in pigs (Sillence and Etherton, 1987). Thus, a single blood sample during the course of the day seems to be sufficient to characterize the SmC status. In contrast, Binnerts et al. (1982) and Falconer et al. (1980) reported diurnal variations of somatomedin-like activity which is, however, not identical with the specifically and radioimmunologically measured $\mathrm{SmC}$ in our investigation. The considerable stability of $\mathrm{SmC}$ levels over a 24-h period is likely to be the consequence of $\mathrm{SmC}$ binding to specific blood plasma proteins (Zapf, Hauri, Waldvogel and Froesch, 1986). One important consequence is a half-life of $\mathrm{SmC}$ in the circulation of several $h$ (Froesch and Zapf, 1985). In addition, protein binding markedly reduces acute biological effects of SmC and is thought to be responsible for absence in vivo of most insulin-like effects found in vitro 

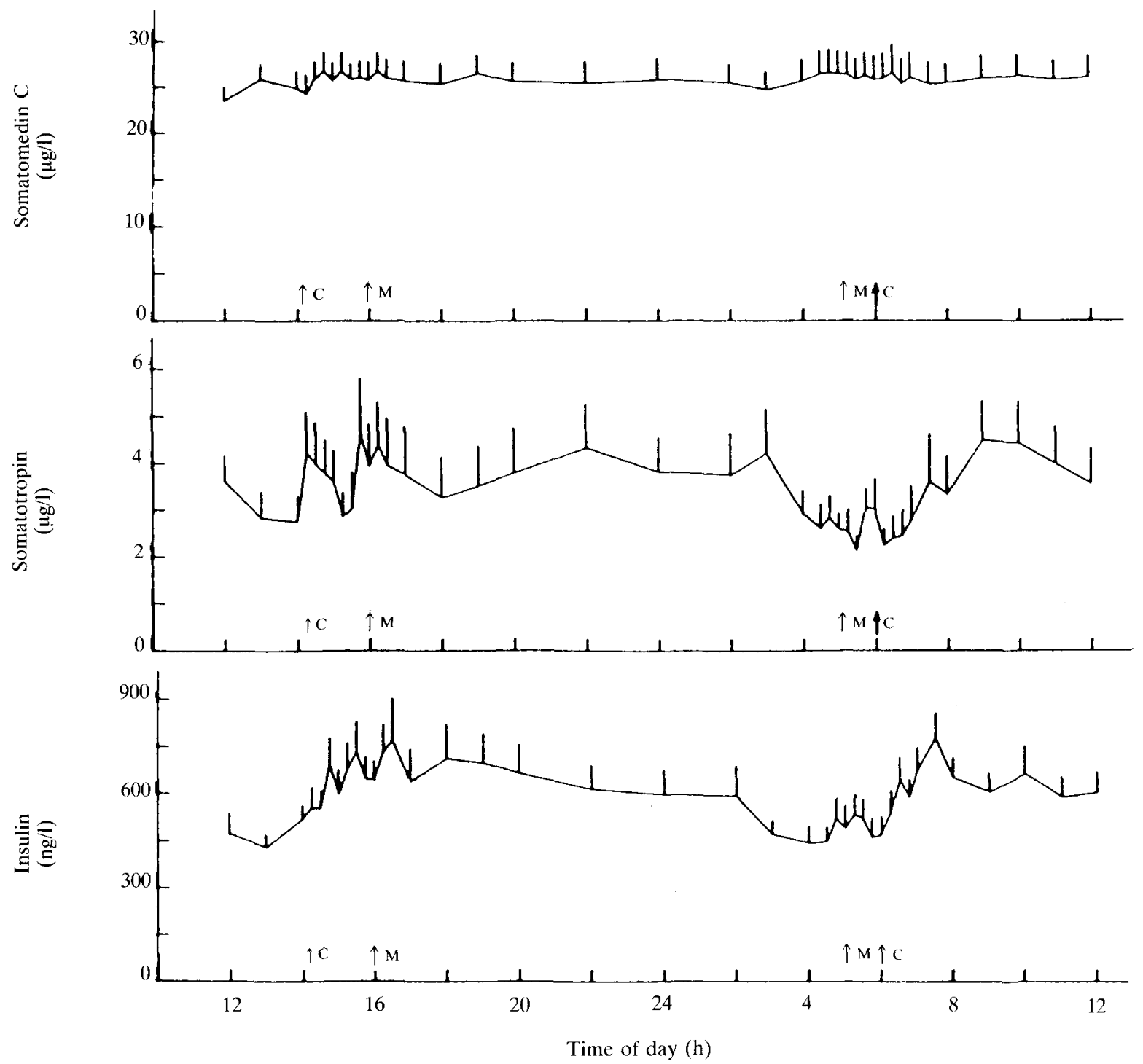

FIG. 6. Blood levels of SmC, STH and IRI during a 24-h period (mean \pm s.e. of all 18 animals of experiment D). Animals received concentrate at 06.00 and at $14.30 \mathrm{~h}(\mathrm{C})$ and were milked at $05.15 \mathrm{~h}$ and at $16.00 \mathrm{~h}(\mathrm{M})$.

(Zapf et al., 1986). IRI consistently increased (Bines, Hart and Morant, 1983) and STH appeared to rise only marginally after the intake of concentrates (irregularly also after milking), and thus are probably more important for rapid regulation of metabolism than SmC.

Our study clearly demonstrates a negative correlation between levels of specifically measured SmC and milk yield. Somatomedinlike activity behaved similarly (Binnerts et al., 1982). In accordance, Falconer et al. (1980) found lower somatomedin-like activity in high, compared with low, yielding cows. Our data also indicate that the presence of a foetus, i.e. pregnancy per se (up to the 7 th month of 
TABLE 4

Body weight, dry matter (basic ration (BR) and concentrates (C)), net energy lactation $(N E L)$ and crude protein $(C P)$ intakes and absorbable protein $(A P)$ intakes and balances, fat-corrected milk yields (FCM), milk composition, blood metabolites and hormones in lactating cows given different amounts of protein and energy (experiment D) $\dagger$

Body weight $(\mathrm{kg})$
BR-intake $(\mathrm{kg} / \mathrm{day})$
C intake $(\mathrm{kg} / \mathrm{day})$
NEL intake $\mathrm{MJ} / \mathrm{day})$
NEL balance $(\mathrm{MJ} / \mathrm{day})$
CP intake $(\mathrm{g} / \mathrm{day})$
AP intake $(\mathrm{g} / \mathrm{day})$
AP balance $(\mathrm{g} / \mathrm{day})$
FCM (kg/day)
Milk fat $(\mathrm{g} / \mathrm{l})$
Milk protein $(\mathrm{g} / \mathrm{l})$
Milk lactose $(\mathrm{g} / \mathrm{l})$
Glucose (mmol/l)
Non-esterified fatty acids ( $\mu \mathrm{mol} / \mathrm{l})$
Ketone bodies $(\mu \mathrm{mol} / \mathrm{l})$
Protein (g/l)
Albumin $(\mathrm{g} / \mathrm{l})$
Urea (mmol/l)
Somatomedin C ( $\mu \mathrm{g} / \mathrm{l})$
Somatotropin $(\mu \mathrm{g} / \mathrm{l})$
Immunoreactive insulin (ng/l)
Triiodothyronine (nmol/l)
Thyroxine (nmol/l)

Body weight $(\mathrm{kg})$

BR-intake $(\mathrm{kg} /$ day $)$

intake ( $\mathrm{kg} / \mathrm{day})$

NEL balance $(\mathrm{MJ} /$ day)

CP intake ( $\mathrm{g} / \mathrm{day})$

AP intake ( $g /$ day)

balance (g/day)

Milk protein $(\mathrm{g} / \mathrm{l})$

Milk protem $(\mathrm{g} / \mathrm{l})$

Ketone bodies ( $\mathrm{mmol} / \mathrm{l}$ )

Urea $(\mathrm{mmol} / \mathrm{l})$

Somatomedin $\mathrm{C}(\mu \mathrm{g} / \mathrm{l})$

Immunoreactive insulin (ng/l)

Thyroxine $(\mathrm{nmol} / \mathrm{l})$

\begin{tabular}{|c|c|c|c|c|c|}
\hline \multicolumn{6}{|c|}{ Group } \\
\hline \multicolumn{2}{|c|}{ LE } & \multicolumn{2}{|c|}{$\mathrm{NE}$} & \multicolumn{2}{|c|}{$\mathrm{CF}$} \\
\hline Mean & s.e. & Mean & s.e. & Mean & s.e. \\
\hline 596 & 15 & 632 & 11 & 650 & 22 \\
\hline $11 \cdot 3$ & $0 \cdot 5^{\mathrm{a}}$ & $11 \cdot 6$ & $0.5^{a b}$ & $13 \cdot 0$ & $0.6^{\mathrm{b}}$ \\
\hline $2 \cdot 7$ & $0 \cdot 2^{a}$ & $6 \cdot 6$ & $0 \cdot 0^{\mathrm{b}}$ & $4 \cdot 6$ & $0 \cdot 0^{\mathrm{c}}$ \\
\hline 88 & $4^{a}$ & 120 & $3^{\mathrm{b}}$ & 128 & $4^{b}$ \\
\hline-40 & $4^{a}$ & -19 & $1^{b}$ & 1 & $4^{c}$ \\
\hline 2188 & $85^{\mathrm{a}}$ & 2630 & $60^{\mathrm{b}}$ & 2648 & $62^{h}$ \\
\hline 1489 & $59^{\mathrm{a}}$ & 1895 & $44^{b}$ & 1994 & $45^{\mathrm{b}}$ \\
\hline-288 & $65^{\mathrm{a}}$ & -41 & $39^{\mathrm{h}}$ & 71 & $46^{\mathrm{b}}$ \\
\hline $30 \cdot 4$ & 1.5 & $31 \cdot 0$ & $1 \cdot 3$ & $29 \cdot 3$ & $2 \cdot 2$ \\
\hline $47 \cdot 8$ & $2 \cdot 7^{\mathrm{a}}$ & 37.7 & $1 \cdot 1^{\mathrm{b}}$ & $32 \cdot 2$ & $2 \cdot 2^{b}$ \\
\hline $34 \cdot 0$ & $0 \cdot 8^{\mathrm{a}}$ & $32 \cdot 0$ & $1 \cdot 1^{\text {ath }}$ & $30 \cdot 3$ & $0 \cdot 3^{b}$ \\
\hline $52 \cdot 7$ & $1 \cdot 1$ & $50 \cdot 7$ & $1 \cdot 5$ & $50 \cdot 5$ & 0.7 \\
\hline $3 \cdot 25$ & 0.19 & $3 \cdot 46$ & 0.03 & $3 \cdot 60$ & $0 \cdot 09$ \\
\hline 257 & $63^{\mathrm{ab}}$ & 145 & $6^{a}$ & 208 & $13^{b}$ \\
\hline 1872 & $363^{a}$ & 995 & $104^{\mathrm{ab}}$ & 852 & $51^{\mathbf{b}}$ \\
\hline $78 \cdot 7$ & $2 \cdot 0$ & $81 \cdot 1$ & $3 \cdot 7$ & $76 \cdot 4$ & $2 \cdot 8$ \\
\hline $42 \cdot 3$ & 0.7 & $43 \cdot 6$ & $1 \cdot 0$ & $44 \cdot 1$ & $1 \cdot 3$ \\
\hline $5 \cdot 42$ & $0 \cdot 47^{\mathrm{ab}}$ & $3 \cdot 90$ & $0 \cdot 39^{\mathrm{a}}$ & $6 \cdot 01$ & $0.71^{\mathrm{b}}$ \\
\hline $17 \cdot 1$ & $3 \cdot 1$ & 23.9 & $2 \cdot 2$ & $27 \cdot 3$ & $4 \cdot 8$ \\
\hline 6.06 & $0.63^{a}$ & $2 \cdot 67$ & $0 \cdot 56^{\mathrm{b}}$ & $1 \cdot 44$ & $0.24^{\mathrm{b}}$ \\
\hline 361 & $39^{a}$ & 713 & $98^{b}$ & 718 & $83^{b}$ \\
\hline $1 \cdot 68$ & $0 \cdot 12^{\mathrm{a}}$ & $2 \cdot 58$ & $0 \cdot 24^{\mathrm{b}}$ & $2 \cdot 28$ & $0 \cdot 15^{\mathrm{h}}$ \\
\hline $53 \cdot 8$ & $5 \cdot 0$ & $68 \cdot 7$ & $6 \cdot 6$ & $58 \cdot 7$ & $4 \cdot 3$ \\
\hline
\end{tabular}

a.b.c Different superscripts indicate significant differences between LE, HE and CF $(P<0.05)$.

$\dagger$ Values are expressed as mean \pm s.e. of $24 \mathrm{~h}$ (39 samples).

pregnancy), does not measurably modify $\mathrm{SmC}$ levels compared with non-pregnant cows. Somatomedins other than SmC, such as insulin-like growth factor II, are considered important for foetal development (Underwood and D'Ercole, 1984; Gluckman, 1986).

Energy and/or protein intake and consequent changes of blood levels of various hormones are known to be determining factors of SmC levels (Breier et al., 1986; Elsasser et al., 1986; Underwood et al., 1986). The experiment lasting over the entire lactation demonstrated a positive correlation between SmC levels and energy and/or protein balance. Interestingly, such a relationship was observed even though balances were always positive in this experiment, because milk production was low.

The fall of $\mathrm{SmC}$ levels after parturition was more marked in cows consciously undersupplied with energy, whereas an additional protein deficiency did not further lower SmC levels. High energy intake in the form of crystalline fat led to increased $\mathrm{SmC}$ levels. Moreover, energy balances were significantly and positively correlated with SmC levels. Thus, energy supply seemed greatly and dominantly to influence circulating $\mathrm{SmC}$, whereas protein supply appeared to be of rather secondary importance. In accordance, in heifers during fasting for 3 days, SmC levels rapidly decreased and 
returned to the normal range within 5 days of refeeding (H. Ronge and J. Blum, unpublished observations). Nevertheless, it has been shown that protein intake in growing steers has decisive effects on $\mathrm{SmC}$ levels (Elsasser et al., 1986) and we also found a positive correlation between $\mathrm{SmC}$ and protein balance. However, energy and protein balances were strongly correlated in our experiments and thus the effects of energy and protein intake and balance are difficult to separate. Microbial protein synthesis in the rumen is greatly dependent on energy supply and there are important interactions between intermediary energy and protein metabolism (Macrae and Lobley, 1984).

Concentrations of STH increased after parturition, as shown previously (Hart, Bines, Morant and Ridley, 1978; Kunz and Blum, 1985). The increase was more marked the greater the degree of energy deficiency and tended to be elevated in cows undersupplied with protein and/or nitrogen, whereas very low STH levels were found in cows given high amounts of energy in the form of crystalline fat, indicating that STH is inversely related to energy intake (Blum et al., 1985a). This is in accordance with other studies in lactating and non-lactating cattle (Hart et al, 1978; Blum, Schnyder, Kunz, Blom, Bickel and Schürch, 1985b) and in other species. STH inhibits lipogenesis and favours lipolysis, enhances gluconeogenesis, stimulates protein deposition and retention of certain minerals and causes insulin resistance (Hart and Johnnson, 1986). Thus, STH is involved in regulation of metabolic changes seen in highyielding dairy cows particularly in early periods of lactation or during energy and protein deficiency. The stimulation of milk production by STH during established lactation is thought to be largely the consequence of enhanced availability of substrates (particularly glucose) to the mammary gland for milk synthesis, in part indirectly due to stimulation of blood flow through the udder, whereas a direct effect on mammary tissue has not yet been demonstrated (Hart and Johnsson, 1986; Karg and Mayer, 1987). How STH enhances the synthetic capacity of individual alveolar cells, which is expected to be a prerequisite for enhanced milk formation, is unclear. However, specific $\mathrm{SmC}$ binding to bovine mammary tissue has been found (Baumrucker, 1986a and b). Thus, SmC could be important for mammary gland growth and alveolar cell regeneration, especially during the dry period. This is partially supported by much higher SmC levels during the 1st day post partum in colostrum than in blood $(\mathrm{H}$. Ronge and J. W. Blum, unpublished observations). It remains to be shown whether SmC is produced locally in the mammary gland, is regulated and has effects distinct from $\mathrm{SmC}$ produced in the liver, i.e. 'systemic' SmC. Because we found low circulating $\mathrm{SmC}$ levels in early lactation, blood SmC effects on mammary tissue may be negligible during this time period.

Somatotropin is well known to enhance the production of $\mathrm{SmC}$ in liver, although a direct effect on $\mathrm{SmC}$ production in bovine liver cells has to our knowledge not yet been demonstrated. Furthermore, SmC levels increased during administration of STH in cattle (Davis, Gluckman, Hart and Henderson, 1987). Therefore, low levels of $\mathrm{SmC}$ in the presence of high concentrations of STH, i.e. a negative correlation between SmC and STH, as found in this study particularly in the first period of lactation, was unexpected. Several causes could be responsible for this paradoxical situation. Because SmC is markedly decreased in fasted animals, including cattle $(\mathrm{H}$. Ronge and $\mathbf{J}$. W. Blum, unpublished observations), the low energy (and protein) supply and hence decreased availability of energy yielding substrates and amino acids, in early lactation could be a primary link. Furthermore, SmC producing liver cells may be less sensitive or responsive to STH during energy and protein deficiency, as found in the rat (Maes, Underwood and Ketelsleger, 1984). Thus, SmC responses to exogenous STH are greatly decreased in heifers after 3 days of fasting and in high-yielding lactating cows in early lactation, as compared with the dry period (H. Ronge and J. W. Blum, unpublished observations). Similarly, $\mathrm{SmC}$ responses to STH were reduced in humans during starvation (Merimee, Zapf and Froesch, 1982). Low circulating insulin and thyroid 
hormone levels, as found in this study, may contribute to a smaller effect of STH on $\mathrm{SmC}$ production because the presence of these hormones is known to be essential for STH to induce its effect in liver tissue and other hormones, such as cortisol, may directly decrease SmC production (Spencer, 1985). In addition, disturbed functioning of liver cells, including $\mathrm{SmC}$ producing cells, as a consequence of energy deficiency (Mills et al., 1986), may also cause reduced SmC synthesis.

High circulating STH and relatively low blood levels of SmC and insulin in early lactation should change metabolism in a direction favouring high milk yield by mobilization and enhanced oxidation of fat, but reduced oxidation of glucose, which is preferentially needed for lactose synthesis. On the other hand, high $\mathrm{SmC}$ and insulin together with normal STH concentrations during the recovery period of lactation and during the dry period can be expected to stimulate deposition of body tissues, such as fat, muscle and bone. The typical changes of $\mathrm{T}_{4}$ and $\mathrm{T}_{3}$ seen also in this study during the lactation cycle seems to be primarily associated with shifts in energy metabolism, especially heat production (Blum, Kunz, Leuenberger, Gautschi and Keller, 1983; Blum et al., 1985a; Kunz and Blum, 1985; Kunz et al., 1985). They are known to modify the sensitivity of various tissues such as the liver to STH (Spencer, 1985) or other hormones. We have also proposed that low $T_{4}$ and $T_{3}$ concentrations in early lactation could help to conserve muscle mass (Blum et al., 1985a). This is thought to be an important effect also of STH, but only when insulin circulates in normal amounts (Bines, Hart and Morant, 1980).

In conclusion, the changes of $\mathrm{SmC}$ seen in these experiments seem to be primarily regulated by energy balance and secondly by protein balance. The reduced production of SmC, while STH is elevated, might additionally be influenced by low insulin, $T_{3}$ and $T_{4}$, as a consequence of the negative energy balances. Thus, rather than a single endocrine factor, only a well orchestrated interplay of various endocrine systems will enable cows finally to produce high amounts of milk.

\section{ACKNOWLEDGEMENT}

This study was supported by a grant of the 'Schweiz. Verband für Künstliche Besamung'. We thank Dr P. Kunz (Institute of Animal Science, Federal Insitituc of Technology, 8092 Zurich) for providing us with the data of glucose, nonesterified fatty acids, ketone bodies and urea of experiment B. Prof. J. Zapf and Mrs I. Einschenk (Laboratory of Metabolism, Department of Internal Medicine, University Hospital of Zurich) are particularly thanked for their great help in development of the radioimmunoassay for the determination of $\mathrm{SmC}$. The technical assistance of Miss C. Morel, Mrs V. Neuhaus, $\mathrm{Mr}$ Barman and $\mathrm{Mr} \mathrm{W}$. Moses is greatly appreciated.

\section{REFERENCES}

Bauman, D. E. and Currie, W. B. 1980. Partitioning of nutrients during pregnancy and lactation: a review of mechanisms involving homeostatis and homeorhesis. Journal of Dairy Science 63: 1514-1529.

BAumRuCkFR, C. R. 1986a. Insulin-like growth factor I (IGF-I) and insulin stimulates lactating bovine mammary tissue DNA synthesis and milk production in vitro. Journal of Dairy Science 69: Suppl. I, p. 120 (Abstr.).

BAumruckek, C. R. 1986b. Insulin-like growth factor I (IGF-I) and insulin stimulates DNA synthesis in bovine mammary tissue explants obtained from pregnant cows. Journal of Dairy Science 69: Suppl. 1, p. 120 (Abstr.).

Brinnink, M. A., Mell.fenberger, R. W., Frobish, R. A. and Bauman, D. E. 1972. Glucose oxidation and entry rate as affected by the initiation of lactation. Journal of Dairy Science 55: 712 (Abstr.).

Bickel, H. and Landis, J. 1978. Das neue System der energetischen Bewertung von Wiederkäuerfutter. Schweizeizerische Landwirtschafliche Monatshefle 56: 280-292.

Bindsi:R, H. 1986 . Verlauf der peripheren Sexualhormonkonzentrationen und der Laktationskurve bei traechtigen und untraechtigen Kuehen. Thesis in Veterinary Medicine, University of Zurich.

Bines, J. A., Hart, I. C. and Morani, S. V. 1980. Endocrine control of energy metabolism in the cow: the effect on milk yicld and levels of some blood constituents of injecting growth hormone and growth hormone fragments. British Journal of Nutrition 43: $179-189$.

Bines, J. A., Hart, I. C. and Morant, S. V. 1983. Endocrine control of energy metabolism in the cow: diurnal variations in the concentration of hormones and metabolites in the blood plasma of beef and dairy cows. Hormone and Metabolic Research 15: 330-334.

Binnerts, W. T.. Adrichem P. W. M. Van, Oudenatrden, C. P. J., Vogt, J. E. and Wassinant, J. E. 1982. Plasma somatomedin in dairy cows: effect of management and feeding levels. Netherlands Milk and Dairy Journal 36: 149-152.

Blum, J. W., Jans, F., Mosfes, W., Fröhli, D., Zfimp, M. WAnnir, M., Hart, I. C., Thun, R. and KEll.F. U. 1985a. Twenty-four-hour pattern of blood 
hormone and metabolite concentrations in high-yielding dairy cows: effects of feeding low or high amounts of starch, or crystalline fat. Zentralblatt für Veterinärmedizin 32: 401-418.

Blum, J. W., Kunz, P., Leuenberger, H., Gautschi, K. and Keller, M. 1983. Thyroid hormones, blood plasma metabolites and haematological parameters in relationship to milk yield in dairy cows. Animal Production 36: 93-104.

Blum, J. W., Schnyder, W., Kunz, P. L., Blom, A. K., Bickel, H. and Schürch, A. 1985b. Reduced and compensatory growth: endocrine and metabolic changes during food restriction and refeeding in steers. Journal of Nutrition 115: 417-424.

Breier, B. H., Bass, J. J., Butler, J. H. and Gluckman, P. D. 1986. The somatrophic axis in young steers: influence of nutritional status on pulsatile release of growth hormone and circulating concentrations of insulin-like growth factor I. Journal of Endocrinology 111: 209-215.

Campbell, P. G. and Baumrucker, C. R. 1986. Characterization of insulin-like growth factor$1 /$ somatomedin $\mathrm{C}$ receptors in the bovine mammary gland. Journal of Dairy Science 69: Suppl. 1, p. 163 (Abstr.).

Chilliard, Y. 1987. [Literature survey: body composition and lipid metabolism in adipose tissues and liver during pregnancy and lactation. 2. In the ewe and the cowl. Reproduction, nutrition, Développement 27: 327-398.

Chilliakd, Y., Rémond, B., Sauvant, D. and Vermorel, M. 1983. Particularités du métabolisme énergétique des hautes productrices do lait. Bulletin Technique Centre de Recherches Zootechniques et Veterinaires de Theix, INRA 53: 37-64.

Clement, C. 1988. Adaptations métaboliques et endocrinologiques à différents déficits protéiques chez des vaches à hautes productions laitières. Thesis in Veterinary Medicine, University of Berne.

Collier, R. J., McNamara, J. P., Wall.ace, C. R. and DehOFF, M. H. 1984. A review of endocrine regulation of metabolism during lactation. Journal of Animal Science 59: 498-510.

Daughaday, W. H., Mariz, I. K and Blethen, S. L. 1980. Inhibition of access of bound somatomedin to membrane receptor and immunobinding sites: a comparison of radioreceptor and radioimmunoassay of somatomedin in native and acid-ethanol-extracted serum. Journal of Clinical Endocrinology and Metabolism 51: 781-788.

Davis, S. R., Gluckman, P. D., Hart, I. C. and HENDERSON, H. V. 1987. Effects of injecting growth hormone or thyroxine on milk production and blood plasma concentrations of insulin-like growth factor I and II in dairy cows. Joumal of Endocrinology 114: 17-24.

Elsasser, T. H., Rumsey, T. S. and Hammoni, A. C. 1986. Dietary regulation of plasma somatomedin $\mathrm{C}$ in beef cattle. American Journal of Clinical Nutrition 43/6: 149 (Abstr.).

Faiconer, J., Forbes, J. M., BINES, J. A., ROY, J. H. B. and HART, I. C. 1980, Somatomedin-like activity in cattle: the effect of breed, lactation and time of day. Journal of Endocrinology 86: 183-188.
Froesch, E. R. and ZAPF, J. 1985. Insulin-like growth factors and insulin: comparative aspects. Diabetologia 28: $485-493$.

Gluckman, P. D. 1986. The regulation of fetal growth. In Control and Manipulation of Animal Growth (ed. P. J. Buttery, D. B. Lindsay and N. B. Haynes), pp. 85-104. Butterworths, London.

HART, I. C. 1983. Endocrine control of nutrient partition in lactating ruminants. Proceedings of the Nutrition Society 42: 181-194.

Hart, I. C., Bines, J. A., Mornnt, S. V. and Ridley, J. L. 1978. Endocrine control of energy metabolism in the cow: comparison of the levels of hormones (prolactin, growth hormone, insulin and thyroxine) and metabolites in the plasma of high- and low-yielding cattle at various stages of lactation. Journal of Endocrinology 77: 333-345.

Hakt, I. C., Flux, D. S., Andrews, P. and McNeilly, A. S. 1975. Radio-immunoassay for ovine and caprine growth hormone: its application to the measurement of basal circulating levels of growth hormone in the goat. Hormone and Metabolic Research 7: 35-40.

HART, I. C. and Johnsson, I. D. 1986. Growth hormone and growth in meat producing animals. In Control and Manipulation of Animal Growth (ed. P. J. Buttery, D. B. Lindsay and N. B. Haynes), pp. 135-159. Butterworths, London.

Honegger, A. and Humbei, R. E. 1986. Insulin-like growth factor I and II in fetal and adult bovine serum. Journal of Biological Chemistry 261: 569-575.

KARg, H. and MAYer, H. 1987. Manipulation der Laktation. Uebersichten zur Tierernährung 15: 29-58.

KLApper, D. G., Svoboda, M. E. and WYK, J. J. VAN. 1983. Sequence analysis of somatomedin $C$ : confirmation of identity with insulin-like growth factor I. Endocrinology 112: 2215-2217.

Kunz, P. and Buum, J. W. 1985. Relationships between energy balances and blood levels of hormones and metabolites in dairy cows durifing late pregnancy and early lactation. Zeitschrift für Tierphysiologie, Tierernährung und Futtermittelkunde 54: 239-248.

Kunz, P. L., Blum, J. W., Hart, I. C., Bickel, H. and Landis, J. 1985. Effects of different energy intakes before and after calving on food intake, performance and blood hormones and metabolites in dairy cows. Animal Production 40: 219-231.

LANDIS, J. 1979. Dic Energie- und Proteinversorgung der Milchkuh. Schweizerische Landwirtschafiliche Monatshefte 57: 381-390.

Leuenberger, H., Kunz, P. and Michel, A. 1987. Die Fütterung der Milchkuh ohne Kraftfutter. Schriften der Schweizerischen Vereinigung für Tierzucht 68: 47-62.

McCutcheon, S. N. and Bauman. D. E. 1986. Effect of pattern of administration of bovine growth hormone on lactational performance of dairy cows. Journal of Dairy Science 69: 38-43.

MACrAe, J. C. and LOBley, G. E. 1984. Interactions between energy and protein. In Control of Digestion and Metabolism in Ruminams (ed. L. P. Milligan, W. L. Grovum and A. Dobson), pp. 367-385. Reston Books, New Jersey.

Mafs, M., Underwood, L. E. and Ketelsi.egfir. J.-M. 1984. Low serum somatomedin-C in protein deficiency: 
relationship with changes in liver somatogenic and lactogenic binding sites. Molecular and Cellular Endocrinology 37: 301-309.

Merimee, T. J., Zapf. J. and Froesch, E. R. 1982. Insulin-like growth factors in the fed and fasted states. Journal of Clinical Endocrinology and Metabolism 55: 999-1002.

Mills, S. E., Bertz, D. C. and Young, J. W. 1986. Characterization of metabolic changes during a protocol for inducing lactation ketosis in dairy cows. Journal of Dairy Science 69: 352-361.

MoE, P. W. 1981. Energy metabolism of dairy cattle. Journal of Dairy Science 74: 1120-1139.

Oldham, J. D., Broster, W. H., Napper, D. J. and Siviter, J. W. 1979. The effect of a low-protein ration on milk yield and plasma metabolites in Friesian heifers during early lactation. British Journal of Nutrition 42: 149-162.

Oltner, R. and Wiktorsson, H. 1983. Urea concentrations in milk and blood as influenced by feeding varying amounts of protcin and energy to dairy cows. Livestock Production Science 10: 457-467.

Rémésy, C., Chilliard, Y., Rayssiguitr, Y., Mazur, A. and Démigné, C. 1986. Le métabolisme hépatique des glucides et des lipides chez les ruminants: principales interactions durant la gestation et la lactation. Reproduction, Nutrition, Développement 26: 205-226.

Sal-acinski, P. R. P., Mclean, C., Sykes, J. E. C., Clement-Jones, V. V. and Lowry, P. J. 1981. lodination of proteins, glycoproteins, and peptides using a solid-phase oxidizing agent, 1,3,4,6-tetrachloro-3, 6-diphenyl glycoril (Iodogen). Analytical Biochemistry 117: 136-146.

Silience, M. N. and Etherton, T. D. 1987.
Determination of the temporal relationship between porcine growth hormone, serum IGF-I and cortisol concentrations in pigs. Journal of Animal Science 64: 1019-1023.

Spencer, G. S. G. 1985. Hormonal systems regulating growth. A review. Livestock Production Science 12: 31-46.

TuCKer, H. A. 1981. Physiological control of mammary growth, lactogenesis and lactation. Journal of Dairy Science 64: 1403-1421.

Tucker, H. A. and Merkel, R. 1987. Applications of hormones in the metabolic regulation of growth and lactation in ruminants. Federation Proceedings 46: 300-306.

Underwood, L. E., Clemmons, D. R., Maes, M., D'ErCol.t, A. J. and Kerelslegers, J.-M. 1986. Rcgulations of somatomedin-C/insulin-like growth factor I by nutrients. Hormone Research 24: 166-176.

Underwood, L. E. and D'Ercole, A. J. 1984. Insulin and insulin-like growth factors/somatomedins in fetal and neonatal development. Clinics in Endocrinology and Metabolism 13: 69-89.

ZapF, J. Hauri, C., Waldvogel, M. and Froesch, E. R. 1986. Acute metabolic effects and half-lives of intravenously administered insulin-like growth factor I and II in normal and hypophysectomized rats. Journal of Clinical Investigation 77: 1768-1774.

ZAPF, J., Walter, H. and Froesch, E. R. 1981. Radioimmunological determination of insulin-like growth factor I and II in normal subjects and in patients with growth disorders and extrapancreatic tumor hypoglycemia. Journal of Clinical Investigation 68: 13211330.

(Received 27 September 1987-Accepted 8 April 1988) 